DIW BERLIN

Discussion

Papers

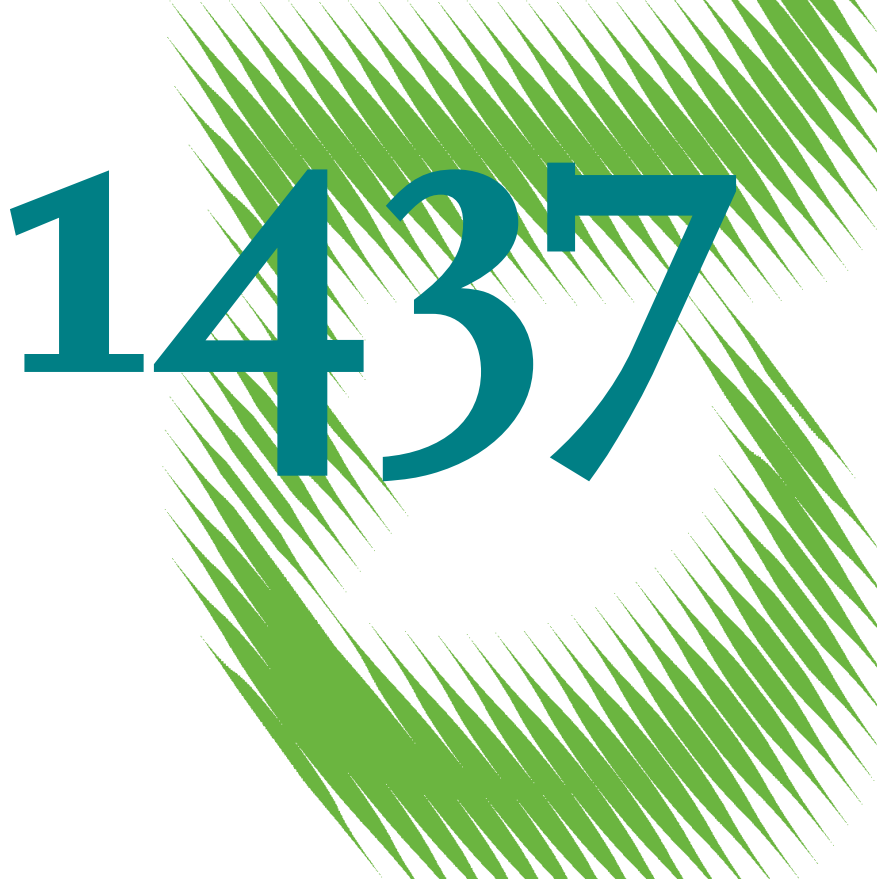

Trade Policy Uncertainty and the WTO 
Opinions expressed in this paper are those of the author(s) and do not necessarily reflect views of the institute.

IMPRESSUM

(C) DIW Berlin, 2014

DIW Berlin

German Institute for Economic Research

Mohrenstr. 58

10117 Berlin

Tel. +49 (30) $89789-0$

Fax +49 (30) $89789-200$

http://www.diw.de

ISSN electronic edition 1619-4535

Papers can be downloaded free of charge from the DIW Berlin website:

http://www.diw.de/discussionpapers

Discussion Papers of DIW Berlin are indexed in RePEc and SSRN:

http://ideas.repec.org/s/diw/diwwpp.html

http://www.ssrn.com/link/DIW-Berlin-German-Inst-Econ-Res.html 


\title{
Trade Policy Uncertainty and the WTO
}

\section{Valeria Groppo and Roberta Piermartini ${ }^{\mathrm{b}}$}

\author{
a German Institute for Economic Research (DIW Berlin), Mohrenstr. 58, 10117 Berlin, \\ Germany. Email: vgroppo@diw.de \\ ${ }^{\mathrm{b}}$ World Trade Organization (WTO), Rue de Lausanne 154, CH-1211 Geneva 21, Switzerland. \\ Email: Roberta.Piermartini@wto.org
}

19 December 2014

\begin{abstract}
Do WTO commitments reduce the risk of trade policy reversals? To address this question, we rely on the theoretical model of varying cooperative tariffs by Bagwell and Staiger (1990) to specify our empirical model for the probability of a tariff increase. We then study how WTO tariff commitments affect this probability. We estimate our model using a database of WTO bound tariffs that we built for all WTO Members from 1996 to 2011 at the HS 6-digit level of disaggregation. Our results show that WTO commitments significantly reduce the probability of a tariff increase, even when the bound tariff is above the MFN applied rate. In addition, the WTO reduces trade policy uncertainty through its monitoring function. These results are robust to including political economy explanations of tariff changes and to addressing endogeneity concerns.
\end{abstract}

Keywords: Gains from trade agreements, commitments, tariffs formation, binding overhang

JEL codes: F1, F5 


\section{Disclaimer and acknowledgements}

This paper does not represent the views of the WTO. The views expressed are those of the authors and do not necessarily reflect, officially or unofficially, those of the WTO or its Members, nor the position of any staff members. Any errors are the fault of the authors. Valeria Groppo worked on this project as a consultant for the WTO. We are indebted to Marc Bacchetta for his valuable contribution to an earlier version of this paper. We thank Eric $\mathrm{Ng}$ Sing and Adelina Mendoza for the assistance provided in extracting the raw data on bindings and MFN applied tariffs, Alya Belkhodja for the data on the European Union's commitments during the Uruguay Round, Alberto Osnago for his assistance on PTA data and Zheng Wang for the data on trade policy reviews. We also thank Chad Bown, Robert Gulotty, Kyle Handley, Nuno Limão, Aaditya Mattoo, the participants to the Conference on Valuing International Trade Rules Conference in Pfäffikon 2009, ETSG 2012, the 2013 WTO/WorldBank/IMF conference and the Geneva Trade and Development Workshop (GTDW) for their useful comments and suggestions. 
The real question is whether

a WTO binding set above the previously applied"(unbound) tariff

has any effect at all."(Bagwell and Staiger, 2011 p.1254)

\section{Introduction}

During the financial crisis starting in 2008, economists and policy practitioners highlighted the risk that, like in the 1930s, the crisis may have spurred a trade war. Several sources have recorded an increase in protectionism. The WTO monitoring report on G-20 trade measures (2014), for example, counts 1,185 new trade restrictive measures between 2008 and 2012. Nevertheless, protectionist responses to the crises on overall trade have been well below any pessimistic prediction. Import restrictive measures implemented by G-20 economies over the October 2008-October 2014 period only cover around 4.1 percent of world merchandise imports and around 5.3 percent of G-20 imports.

The discipline imposed by trade agreements may have dampened trade policy volatility. Indeed, policymakers have long indicated that the predictability of trade policy is an important benefit of trade agreements, and jurisprudence has found that "security and predictability" are among the goals of the WTO Agreement, as well as of the GATT $1994 .{ }^{2}$ However, WTO commitments set ceiling tariff rates that cannot be exceeded rather than rigid rates. Countries have bound tariffs at levels often substantially above those of applied tariffs. As of 2011, in most of the developing world some 70 to 90 percent of tariffs could be increased unilaterally by more than 15 percentage points without violating WTO commitments (WTO, 2009). In addition, under specified conditions, WTO agreements allow for the possibility to increase tariffs above the binding rate through safeguards, antidumping and countervailing duties. As an ultimate form of flexibility, countries may also increase tariffs in breach of the agreement without triggering a trade war to the extent that this is a temporary measure that is withdrawn before beginning a dispute at the WTO. A key question is, therefore, whether WTO bindings are an effective or realistic limitation of a country's discretion to use its trade policy in reaction to a shock.

Understanding the determinants of trade policy uncertainty and the role of trade agreements in this respect is important for at least two reasons. First, trade policy uncertainty hinders trade. Exporters value the risk associated with a possible increase in barriers to trade in the destination market when deciding whether to export, and delay exports to risky destinations. Focusing on Australia, for

\footnotetext{
${ }^{2}$ See Report of the Appellate Body (2005) "United States-Measures Affecting the Cross-Border Supply of Gambling and Betting Services", WT/DS285/AB/R, para. 188; Report of the Panel (1993) on "EEC-Member States' Import Regimes for Bananas", DS32/R para. 130; Report of the Panel (1985) on "United States Manufacturing Clause", BISD 31S/74.
} 
example, Handley (2014) shows that market entry is higher in sectors characterised by lower binding overhangs (the gap between the bound and the applied tariff rate). In another paper, Handley and Limão (2012) show a significant increase in Portuguese exports to the EU upon accession, even in sectors where the applied tariff did not change. They interpret this as evidence that Portugal's accession to the EU eliminated the (pre-accession) risk that tariffs faced by Portuguese exporters may increase to the level of EU external tariffs. ${ }^{3}$ Handley and Limão (2014) estimate that reducing policy uncertainty explains 22 percent of China's export growth to the U.S. following its 2001 WTO accession.

Second, recent literature points at a possible uncertainty-reducing motive for trade agreements. ${ }^{4}$ For example, Limão and Maggi (2013) show that a risk-averse government may have an incentive to sign uncertainty-reducing trade agreements, the greater its risk to suffer from a counter-cyclical tariff imposed by the importing country. Beshkar et al. (2012) show that when governments have private information about the magnitude of shocks, optimal agreements limit large countries' discretion to respond to these shocks. This is because negotiators take into account that large countries have an incentive to over report the magnitude of shocks and increase their tariffs accordingly, in order to take advantage of their market power.

As yet, the hypothesis that the WTO reduces trade policy uncertainty is largely untested. Rose (2005) and Mansfield and Reinhardt (2008) study the impact of WTO membership on trade volatility, but not on trade policy. Rose (2004) studies the impact of WTO membership on trade policy, but focuses on the level of tariffs rather than their variability. Cadot et al. (2010) show that WTO membership weakly impacts agricultural trade policy variability. However, Cadot et al. (2010)'s measure of trade policy volatility includes changes in the ad valorem equivalents of trade barriers. In agriculture, many barriers to trade take the form of specific duties or quotas. For these measures, the ad valorem equivalents change when prices change, even without a change in trade policy.

In this paper, we analyse the impact of WTO commitments on changes in MFN applied tariffs, isolating pure trade policy changes from any other change in the level of protection due to market conditions by focusing on ad valorem tariffs. We measure trade policy uncertainty as the probability

\footnotetext{
${ }^{3}$ Other papers pointing at the importance of trade policy uncertainty for trade include Freund and Pierola (2010a, 201b) and Sala et al. (2010)

${ }^{4}$ In general, theoretical models explain trade agreements as a means to manage the level of trade barriers, not their variability (Bagwell and Staiger, 1999a; Maggi and Rodriguez-Clare, 1998).
} 
of a tariff increase (rather than tariffs' volatility) to account for the fact that it is only the prospect of a bad shock that affects an exporter's decision of whether to enter a certain market. ${ }^{5}$

We model MFN applied tariff increases in bound tariff lines as changes in cooperative tariffs. Like Bown and Crowley (2013), we rely on Bagwell and Staiger (1990)'s (hereafter B\&S) theoretical model of varying cooperative tariffs to specify our empirical model. Consistent with B\&S, we only include bound tariff lines in our sample, and we specify MFN applied tariff changes as a function of the size and variability of unexpected import surges, and the importing country’s market power.

We then augment the basic B\&S model with a measure of trade policy flexibility. For this, we alternatively use the bound rate, the gap between the bound and the applied tariff rate (the so called water), and the gap between the prohibitive tariff and the applied rate (which we call effective water).

To estimate this model, we build a database of bound tariff rates for the 1996-2011 period, at the HS 6-digit level, for WTO Members. Commonly, under the WTO agreements, countries commit to gradually reduce their bound rate from a certain base rate to a final bound rate within a certain time period. The bound rate in force, therefore, changes over time. However, the WTO Consolidated Tariff Schedules (CTS) database only reports the schedules for the final bound rates. In order to build the historical series of bound rates, we collected information from several sources including WTO negotiating practices during the Uruguay Round.

This new database allows us to measure the proportion of global trade that occurs under flexible trade policy regimes and to assess, for the first time, its evolution over time. We find that the percentage of imports for unbound sectoral lines, or lines characterised by a gap between the bound and the applied tariff rate above 5 percentage points, varies from a minimum of approximately 23 percent in 2003 to a maximum of about 33 percent in 2008. More importantly, we show that variations in trade policy space are not just due to changes in the applied rate, but also changes in the bound rate. The bound coverage has increased from 67 to 80 percent since the Uruguay Round. The average bound rate has decreased by 3 percentage points, with a reduction of over 8 percentage points for middle and low income countries. Overall, there are 779,372 bound tariff rate changes involving 9.3 percent of trade over the whole period. ${ }^{6}$

\footnotetext{
5 "When a firm enters, it weighs the expected PDV (present discounted value) of profits from entering today against the value of waiting for a better shock in the future. Because good news in the future is offset by the opportunity cost of entry, only bad news matters when the entry investment is irreversible" (Handley, 2014, p. 54).

${ }^{6}$ The percentage of imports with a bound tariff change represents the percentage of imports at time $t-1$, for which we register an increase in the bound rate at time $t$.
} 
We find that WTO flexibility is an important determinant of the risk of trade policy reversal. The probability of a tariff increase rises with the gap between bound and applied rate. On the basis of our estimates, we calculate that, absent WTO commitments (that is, if a country's policy flexibility was only to be determined by its prohibitive tariff), the probability of a trade policy reversal would increase by 9.5 percentage points, on average and ceteris paribus. This means that, absent the WTO, we would have experienced tariff increases on 9.5 per cent of tariff lines more than we have done, for each country and each year (approximately 490 tariff lines at the HS 6-digit level). In addition, our results broadly support B\&S model of time varying cooperative tariffs. We find that MFN applied tariffs increases are more likely, the larger the import surge in sectors where these import shocks are less common and when market power is higher.

Our results are compelling for two reasons. First, we show that the terms-of-trade (TOT) hypothesis for trade agreements matters for a common case, that of MFN applied tariffs changes. We show this for a sample of over 100 countries between 1996 and 2011. Recent studies looking into this question focus on more specific cases. Bown and Crowley (2013) examine anti-dumping measures adopted by the United States over the 1997-2006 period. Broda et al. (2008) look at tariff schedule of non-WTO countries. Bagwell and Staiger (2011) study the impact of WTO accession on reducing tariffs from the level of non-cooperative to that of cooperative tariffs in 16 recently acceded countries. Ludema and Mayda (2013) test the TOT hypothesis on the MFN applied tariffs averaged over several years for a sample 36 countries. Our approach differs from theirs as we test the TOT hypothesis on the overtime variations of the MFN applied tariffs. Second, we also provide the first evidence that, as suggested by Limão and Maggi (2013), there might be an uncertainty-reducing motive beyond a tariff reducing motive for entering trade agreements by showing that tariff bindings restrain applied tariffs even when gaps between the two exist.

We also show that this model can be used to address some long-standing questions in the trade literature. In particular, we contribute to the debate over whether protectionism is counter-cyclical by looking at the relationship between the economic cycle and the probability of tariff increases. ${ }^{7} \mathrm{By}$ controlling for a country's participation in preferential trade agreements, we also gain insights as to whether multilateral and preferential liberalization are substitutes or complements. ${ }^{8}$ Furthermore, we test whether other aspects of WTO functions, such as its monitoring activity, matter for trade policy predictability. Finally, we include traditional political economy determinants of tariffs -employment and the value added to output ratio- that are commonly identified as important factors in determining

\footnotetext{
${ }^{7}$ Several studies argue that protectionism during increases economic crises (see, for example, Bohara and Kaempfer, 1991; Grilli, 1988; Knetter and Prusa, 2003); however, more recently Rose (2013) challenges this argument.

${ }^{8}$ See, for example Bagwell and Staiger (1999), Bond and Syropoulos (1996), Freund (2000), Ornelas (2007), and Estevadeordal et al. (2008).
} 
tariff variations. ${ }^{9}$ Our findings support the view that MFN applied tariffs are counter-cyclical, that multilateral and preferential tariffs are substitutes, that transparency and monitoring activity by the WTO contributes to predictability of trade policy, as well as that MFN applied tariffs respond to lobby pressure of large sectors. Most importantly, the inclusion of these variables does not affect our key finding on the value of bindings.

Our results are robust to addressing endogeneity concerns. In particular, we tackle the problem of potential endogeneity of the binding rates (whereby commitment to low bound rates are taken in tariff lines where flexibilities are less needed) by instrumental variables estimation (IV). To instrument for WTO flexibility measures, we use two variables. First, the countries' average imports before accession. This is a proxy for market power that captures the extent of the international costshifting motive for cooperation. Second, we use the applied tariff in the period before accession, to reflect the practice that tariffs applied by a country before its accession to the WTO are a starting point for negotiations.

The rest of the paper is structured as follows. Section 2 describes the data. It explains how we constructed the database of historical binding rates and discusses the evidence on the magnitude of trade policy flexibility and trade policy uncertainty. Section 3 introduces our empirical strategy. Section 4 provides the results for our basic specification. Section 5 extends the model to a number of institutional, economic and political determinants of trade policy. Section 6 shows the results of our robustness tests for the size of tariff changes, endogeneity and political economy determinants of tariff changes. Section 7 concludes.

\section{Tariff bindings and tariff changes}

Under GATT/WTO, market access commitments take the form of tariff bindings. These are not rigid values, but ceiling tariff rates, below which WTO Members are free to move their tariffs. In the Uruguay Round countries committed to a substantial increase in the number of bound tariff lines. Today, virtually all tariffs on agricultural products are bound and many countries have bound all their tariffs. However, the level of the bound rate is often well above the level of the applied tariff.

Little is known about the portion of global trade under flexible trade policy regime and its changes overtime. Existing studies on tariff overhang typically use data on the final bound rate (WTO, 2009; Foletti et al., 2011). This is the bound tariff rate to which countries commit to reduce their bound rate

\footnotetext{
${ }^{9}$ See, for example, Finger et al. (1982), Crowley (2011), Bown and Crowley (2013).
} 
by a certain date. However, this date does not always coincide with the year of entry into force of the agreement, because often countries commit to reduce the bound rate gradually from an initial base rate to the final rate, over an implementation period. The bound rate in force changes over time, as does the MFN applied tariff rate. Therefore, the degree of flexibility of global trade as measured by the tariff overhang (or water) also varies.

In order to measure the portion of global trade under flexible trade policy regimes (i.e. such that countries can change their MFN applied tariff without violating the WTO agreement) and study the relationship between WTO commitments and tariff changes, we built the time series of bound tariffs in force between 1996 and 2011 -this database is new, as the WTO does not provide data on the evolution over time of bound rates- and merge it with data on MFN applied rates and trade flows at HS 6-digit level.

\subsection{Building the database of historical bound tariffs}

The WTO CTS database provides information on WTO Member commitments at the tariff line level. This includes the final bound rate, the base rate as well as the starting and end dates of the implementation period. Using this information, together with additional information on the UR commitments ${ }^{10}$ and WTO practice, we construct the time series of bound rates.

The assumptions we used to construct the database are the following:

(i) For the years before the implementation period and after a country accession to the WTO, we set the bound rate equal to the base bound rate. This assumption is supported by the practice that during the Uruguay Round, Members set the base rate of already bound tariff lines equal to the existing bound rates. ${ }^{11}$

${ }^{10}$ For the European Union (EU), we correct the information in the CTS using data from the UR schedules. The CTS database for the EU, reports the bound rate as of December 31, 1999 as base status. As stated in the COVER NOTE of the 'Schedule CXL of the European Communities Consolidated list of concessions', "The base rate shown in the concessions table is the bound rate in force as at 31.12.99 (see also headnote 2 for Agricultural products). This common reference point has been chosen due to the problem of identifying 'the base rate in the most recent negotiations' (there have been a number of negotiations since the UR) as well as nomenclature changes. UR base rates are shown in the correlation tables." In order to build the variable for the binding rate over time (the current bound), we use the Original Correlation Table CXL96CTS99. The base rate provided in these tables is that set at the UR. We use the base rate obtained from the CTS that refers to the situation in 1999 as the final rate for the 1995-1999 period and calculate the yearly bound rate using the standard assumption of a progressive reduction of equal percentage point per year. For some lines (585) we have the MFN applied rate, but the base rate is missing. This is because it is non-ad valorem. We proxy the bound rate with the max between the maximum between the MFN applied and the final bound rate.

${ }^{11}$ See "WTO Schedules of Concessions and Renegotiations of Concession, Module 4". 
(ii) During the implementation period, we assume that the bound rate is reduced gradually (that is, by the same percentage points each year) from the base rate to the final bound rate. The first and last cuts are applied in the first and last year of the implementation period, respectively, so that the final bound rate is reached on the final year of the implementation period. This is the typical evolution agreed upon by WTO Members under the Marrakesh Protocol of the GATT 1994. In fact, at paragraph 2, the Protocol provides that "The tariff reductions agreed upon by each Member shall be implemented in five equal rate reductions, except as may be otherwise specified in a Member's Schedule. The first such reduction shall be made effective on the date of entry into force of the WTO Agreement, each successive reduction shall be made effective on 1 January of each of the following years, and the final rate shall become effective no later than the date four years after the date of entry into force of the WTO Agreement, except as may be otherwise specified in that Member's Schedule...."12

For tariff lines unbound before the Uruguay Round, we set the base rate of the newly bound line equal to the average MFN applied rate in the years before the beginning of the implementation period. Again, we followed Members' common practice of setting the base rates as the MFN applied rates prevailing over a certain reference period.

(iii) For the years after the end of the implementation period, we set the bound rate equal to the final bound rate.

As an example, Figure 1 shows the bound rate of the product line "030233" (denoting Tuna) for Brazil. ${ }^{13}$ Following the Uruguay Round, Brazil committed to reduce its bound rate from 55 to 35 percent over a five year implementation period. As indicated by the continuous line, the bound rate is set equal to the base rate before 1995, it is gradually reduced at equal rate reductions in the period from 1995 to 1999 and remains fixed at the final rate after 1999. In this case, we assume that the bound rate was reduced to 51 percent in 1995 to 47 percent in 1996, to 43 percent in 1997 and so on, until reaching the 1999 final bound rate of 35 percent.

\footnotetext{
${ }^{12}$ For those products for which countries have renegotiated commitments (such as ITA and PHARMA products, Annex 5 agriculture, renegotiations and unilateral commitments), the above assumptions may not be correct as the base rate for the new commitments may not always coincide with bound rate at the time. The total of observations falling in this case is, however, small.

${ }^{13}$ In the HS 1996 nomenclature, code "030233" corresponds to "Tunas (of the genus Thunnus) skipjack or stripe-bellied bonito (Euthynnus (Katsuwonus) pelamis), excluding livers and roes."
} 
Figure 1. From the base to the final bound rate

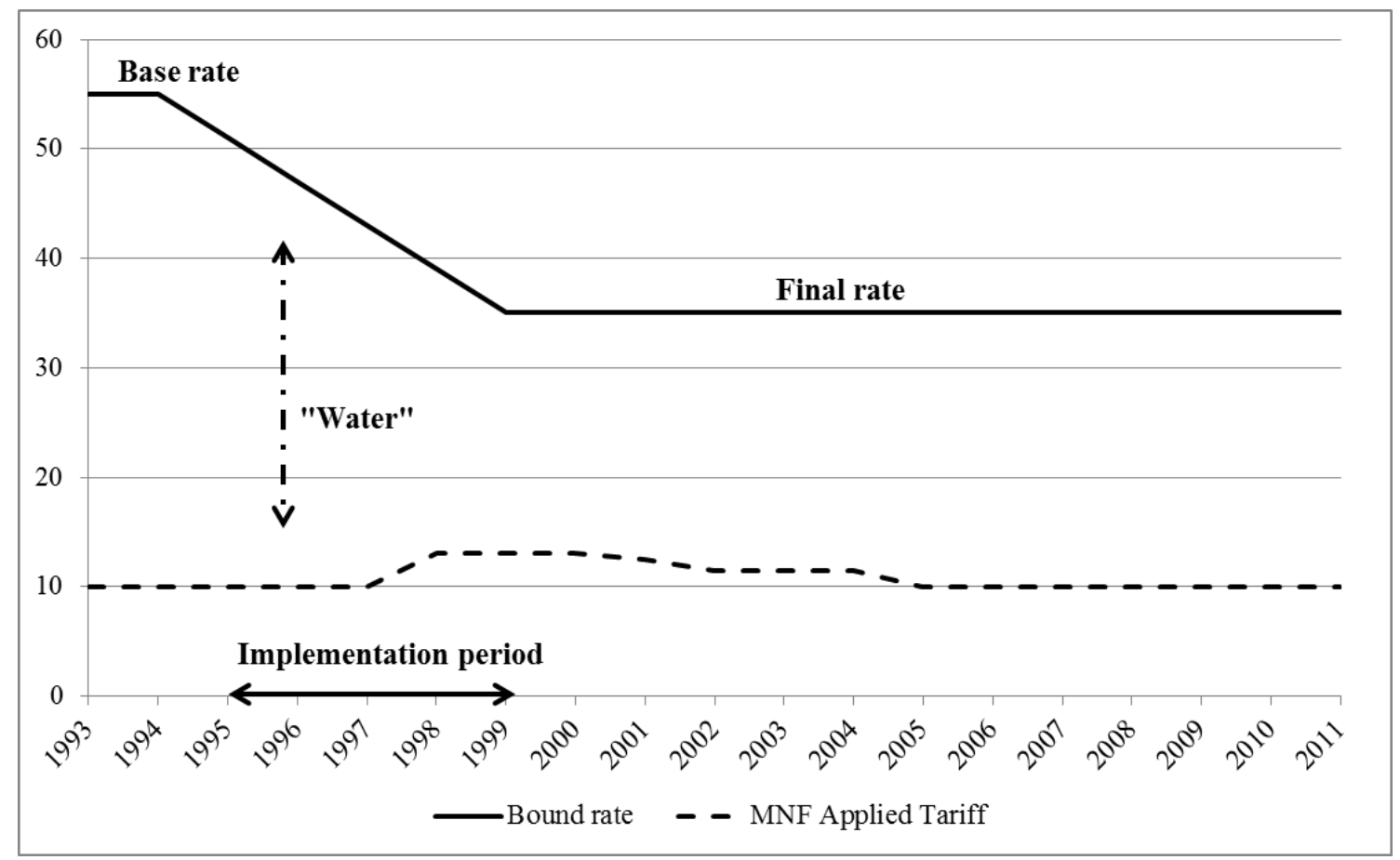

Note: The graph refers to the HS1996 product line "030233" for Brazil. For this line, the country had an implementation period going from 1995 to 1999, with a base rate of 55\% and a final bound rate of 35\%.

\subsection{A descriptive analysis of trade policy regime}

Table 1 shows significant changes in the binding coverage and bound rates over time at the worldlevel, by income as well as by sector. We find that overall the binding coverage increased by about 13 percentage points, passing from 67 to 80 percent between the1996-1998 and 2009-2011 periods. The highest increase in binding coverage is registered for middle and low income countries. This is mainly due to a set of middle-income countries that were not WTO Members in the first period and acceded the Organization during the second period (among them, Albania, Armenia, China, Georgia, and Jordan). At the sectoral level, the binding coverage increased by about 13 and 12 percentage points in the manufacturing and agricultural sector, respectively.

The percentage of global trade under bound regime increased by only 1 percentage point between the two considered periods, without a relevant difference between manufacturing and agriculture. However, within income groups there has been greater variability over time. In particular, the percentage of bound trade increased by about 21 and 7 percentage points in the middle and low income group, respectively. Differently, we register a decline in the percentage of bound trade for the high income country group. This is mainly due to the increase in trade under the following two HS 1996 code lines: 2709-00 (Petroleum, crude) which is unbound for a set of high income countries, 
including the United States, Republic of Korea and Japan; 2710-00 (Petroleum, other than crude) which is unbound for Singapore and Hong Kong (China), among other high income countries.

The global average bound rate declined by about 4 percentage points, going from 30.82 to 27.04 percent. Middle-income countries registered the greatest decrease in the bound rate between the two periods. From a sectoral perspective, we observe a greater reduction in the average bound rate for agriculture than for manufacturing.

Table 1. Bound lines, bound rate and imports under bound regime

\begin{tabular}{|c|c|c|c|c|c|c|}
\hline & \multicolumn{2}{|c|}{ Bound lines (percent) } & \multicolumn{2}{|c|}{$\begin{array}{c}\text { Trade under bound regime } \\
\text { (percent) }\end{array}$} & \multicolumn{2}{|c|}{$\begin{array}{l}\text { Bound rate } \\
\text { (percent) }\end{array}$} \\
\hline & $1996-1998$ & $2009-2011$ & 1996-1998 & 2009-2011 & 1996-1998 & 2009-2011 \\
\hline & (1) & (2) & (3) & (4) & (5) & (6) \\
\hline World & 67.25 & 80.13 & 85.48 & 86.54 & 30.82 & 27.04 \\
\hline High income & 80.12 & 87.10 & 90.39 & 87.47 & 10.08 & 7.72 \\
\hline Middle income & 71.08 & 88.10 & 63.84 & 85.27 & 40.03 & 32.07 \\
\hline Low income & 27.45 & 40.68 & 27.56 & 34.65 & 51.59 & 43.89 \\
\hline G20 & 82.32 & 86.73 & 88.63 & 88.65 & 24.23 & 19.56 \\
\hline Rest of the world & 61.49 & 78.15 & 68.17 & 75.23 & 34.19 & 29.53 \\
\hline NAMA & 64.56 & 77.63 & 85.02 & 86.18 & 26.80 & 23.52 \\
\hline Agriculture & 85.52 & 97.04 & 92.03 & 92.93 & 51.40 & 46.15 \\
\hline
\end{tabular}

Notes: The table reports average values in 1996-1998 and 2009-2011 periods. The sample only includes country-product pairs for which data are available on bound status, bound rate and imports for at least one year in each period. This amounts to a total of 1,612,137 observations, including 65 countries and 324,732 unique country-sector pairs. Appendix table B.1 reports the number of observations included for each country and period. The percentage of bound lines and the percentage of trade under bound regime (columns 1-4) are obtained considering WTO and non-WTO Members. The average bound rate (columns 5 and 6) is calculated considering only WTO Members and bound lines.

A substantial portion of global trade occurs under flexible trade policy regimes. Figure 2 shows the percentage of imports by level of water, between 1996 and 2011. In 2011, on average 27 percent of world imports were either unbound or bound with water greater than 5 percentage points. Over the period of analysis, the percentage of imports under unbound regime or with water greater than 5 percentage points ranged from 23 percent in 2003 to 33 percent in 2008. 
Figure 2. Imports by level of water, 1996-2011

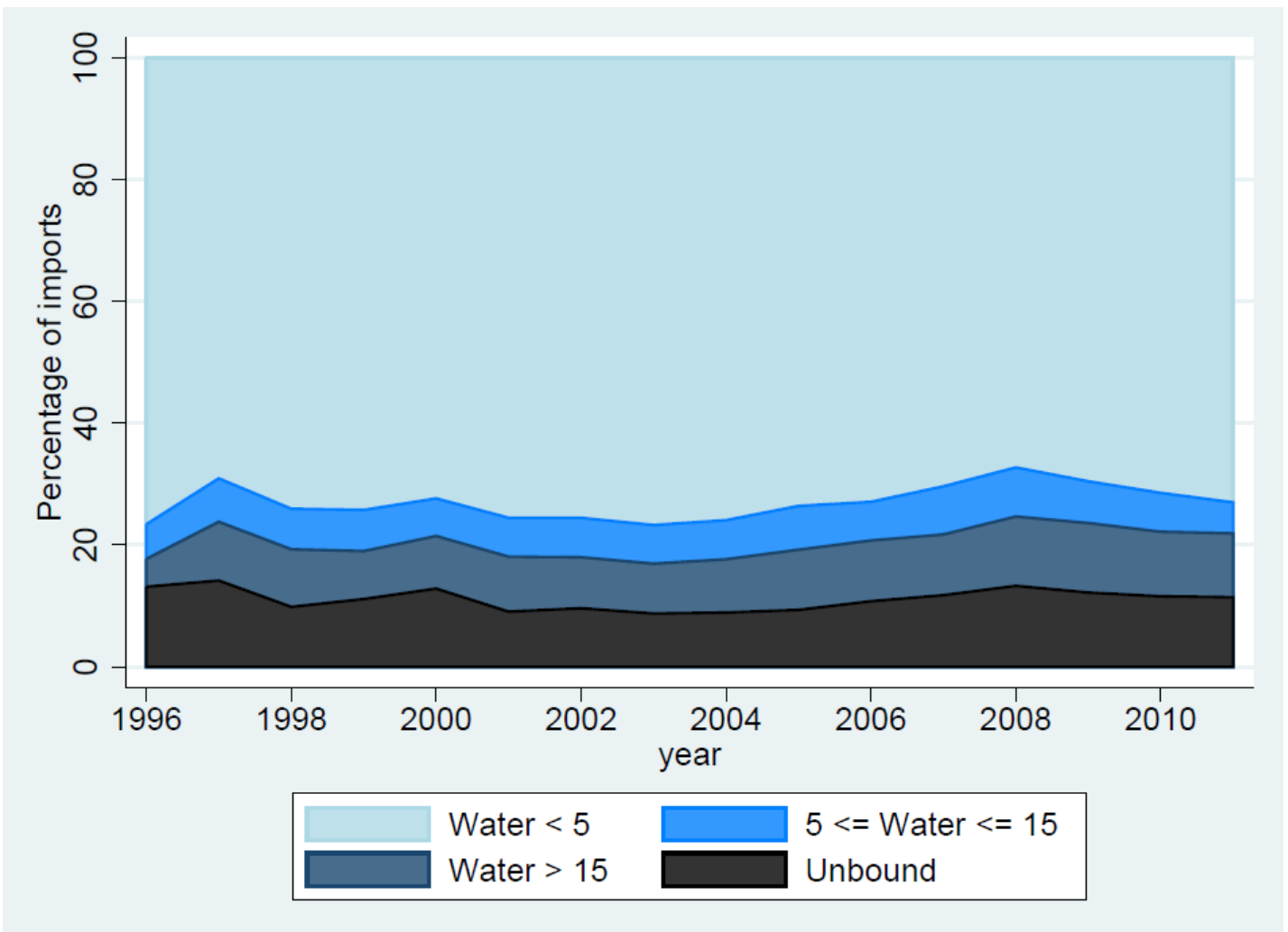

Note: The graph includes those product lines for which we have data on imports, water and binding status for at least one year over the 1996-2011 period. The number of observations included each year varies from a minimum of 119,475 (in year 1996, including 25 countries) to a maximum of 561,072 (in year 2002, including 114 countries).

The extent of trade policy flexibility differs significantly across countries. Figure 3 represents a map of the world, where countries are shown in different colours, based on their level of water (average across sectors), for the most recent available year (darker colours indicate deeper levels of water). In general, developing countries have deeper water. Among the countries having 2011 as the most recent year for which data are available, those with the lowest levels of water (shallow water) are the European Union, Switzerland, Macao (China), Hong Kong, China, Japan, and the United States. The countries with the highest levels of water include Rwanda, Iran, the Solomon Islands, Lesotho, Barbados, and Saint Kitts and Nevis. 


\section{Figure 3. Water in the tariff}

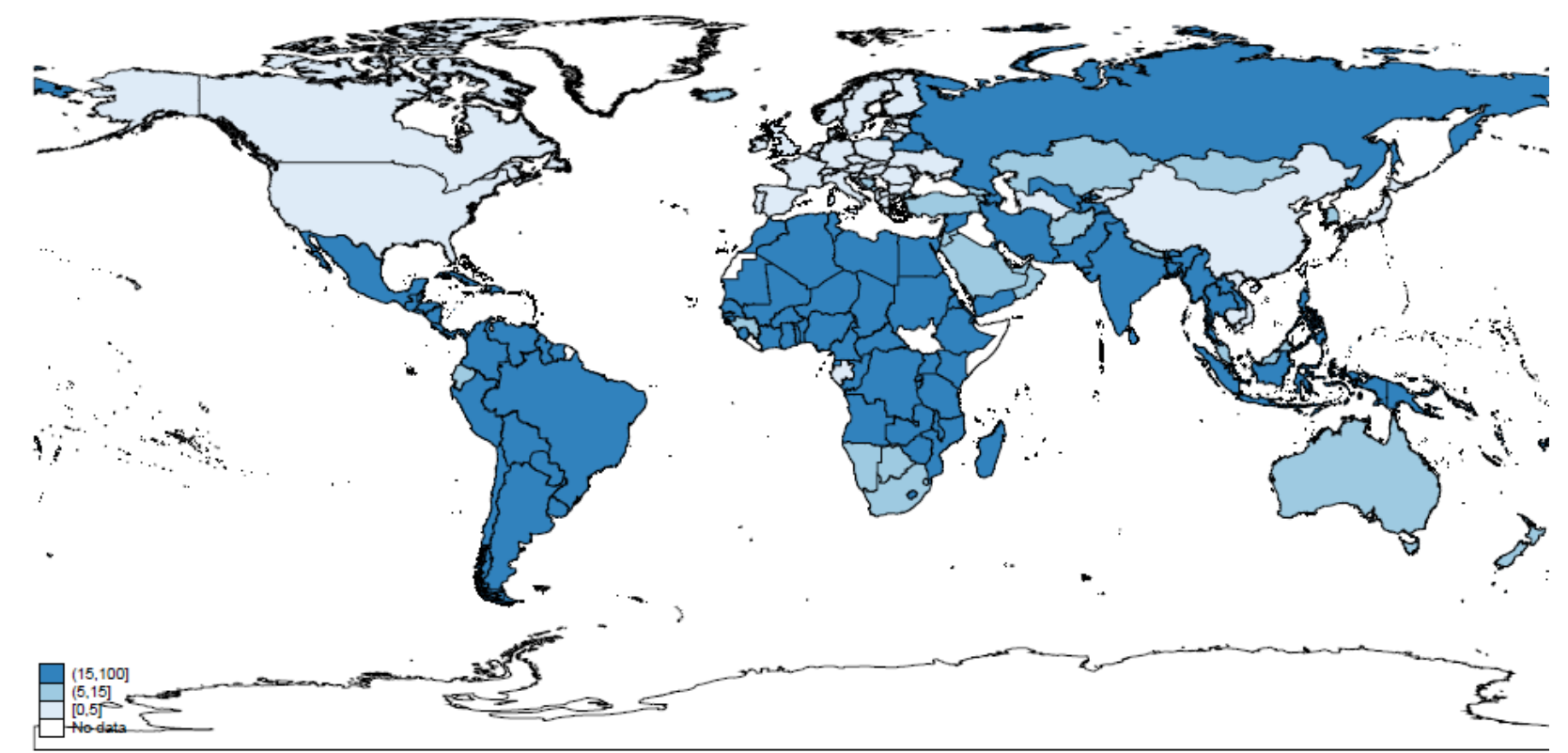

Note: The sample only includes those country-sector pairs with available data on water for at least one year. For each country, the average water in the tariff across sectors for the most recent available year is considered. For the purpose of this chart, we calculated the water for unbound lines as deviation of the applied tariff from the tariff peak (defined as three times the average applied tariff across years).

Table 2 shows the average percentage of trade by level of water in 2009-2011. The global average level of water in the tariffs is about 18 percentage points, ranging from about 4 percentage points in high income countries to approximately 24 percentage points in middle and low income countries. At the sectoral-level, the average level of water is significantly higher in agriculture than in manufacturing.

At the global level, the percentage of trade under unbound regime or with water above 5 percent amounts to about 23.4 percent in the considered period. High income countries are characterised by the largest share of trade with water below 5 percent (89 percent), middle income countries have the largest percentage of trade with water above 15 percent (29 percent), while the percentage of unbound trade is largest for low income countries (62 percent). 
Table 2. Trade under "water," percentage

\begin{tabular}{l|c|c|c|c|c}
\hline & \multicolumn{5}{|c}{ Average 2009-2011 } \\
\hline & $\begin{array}{c}\text { Water } \\
\text { (percentage } \\
\text { points in bound } \\
\text { lines) }\end{array}$ & $\begin{array}{c}\text { Trade with } \\
\text { water }<5 \\
\text { (percent) }\end{array}$ & $\begin{array}{c}\text { Trade with } \\
5<\text { water }<15 \\
\text { (percent) }\end{array}$ & $\begin{array}{c}\text { Trade with } \\
\text { water }>15 \\
\text { (percent) }\end{array}$ & $\begin{array}{c}\text { Unbound trade } \\
\text { (percent) }\end{array}$ \\
\hline & $(1)$ & $(2)$ & $(3)$ & $(4)$ & $(5)$ \\
\hline World & 17.60 & 76.65 & 5.14 & 10.02 & 8.19 \\
High income & 3.55 & 88.90 & 4.32 & 0.61 & 6.18 \\
Middle income & 23.38 & 51.91 & 6.76 & 29.35 & 11.98 \\
Low income & 24.08 & 7.61 & 17.05 & 13.48 & 61.86 \\
& 10.64 & 81.64 & 4.20 & 8.60 & 5.57 \\
G20 & 21.47 & 44.50 & 11.23 & 19.18 & 25.09 \\
Rest of the world & 15.71 & 76.90 & 5.02 & 9.68 & 8.40 \\
& 28.20 & 72.07 & 7.36 & 16.12 & 4.46 \\
NAMA & & & & & \\
Agriculture & & & & & \\
\end{tabular}

Note: The table reports average values in the 2009-2011 period. The sample only includes country product pairs with data on bound status, water and imports for at least one year in the considered period. This amounts to a total of 1,028,051 observations, including 47 countries and 215,894 unique country-sector pairs. Appendix table B.2 reports the number of observations included for each country and period. The average level of water and the percentage of trade with different levels of water (columns 1-4) are computed considering only WTO Members and bound lines. Unbound trade includes trade in unbound lines by WTO Members and trade by non-WTO Members.

\subsection{Trade policy uncertainty: the use of trade policy flexibility}

Countries change their MFN applied tariffs. Over the 1996-2011 period, 150 countries changed at least one tariff line. On average, countries increased about 166 tariff lines each year, corresponding to about 3.4 percent of the total. The average size of a tariff increase across country-year pairs has been 6.7 percent with a maximum of 182.5 (corresponding to Saint Kitts and Nevis in 2002). The average percentage of imports that were subjected to a tariff increase in any country-year is 7.5.

Table 3: MFN applied tariff increases 1996-2011

\begin{tabular}{lcccc}
\hline & Mean & Min & Max & Std. Dev. \\
\hline Number of lines & 166 & 0 & 5,081 & 589.6 \\
Percentage of lines & 3.4 & 0 & 99.4 & 11.8 \\
Size & 6.7 & 0 & 182.5 & 10.3 \\
Percentage of imports covered & 7.5 & 0 & 97.8 & 13.7 \\
\hline
\end{tabular}

Note: Statistics are calculated across country-year pairs. The percentage of imports represents the percentage of imports at time $t-1$, for which we register a tariff increase at time $t$. The sample only includes country-product pairs with available data on lagged imports and tariff change in at least one of the years 1997-2011. This amounts to a total of 6,064,077 observations, including 48 countries and 1,273 unique country-year pairs. 
Tariff increases are particularly relevant in some countries and sectors. Appendix table C.1 and C.2 show the top 10 countries and sectors, respectively, in terms of number of increases, trade covered and magnitude of the tariff increase.

Tariff changes are related to trade policy flexibility and economic conditions. Figures $4 \mathrm{a}$ and $4 \mathrm{~b}$ show the relationship between tariff increases and the level of water. Interestingly, figure 4a shows a positive correlation between the probability of a tariff increase and the level of water in bound lines. However, tariff increases in unbound lines are less likely than in bound lines (for water greater than 5). This paradox may be explained by the argument (suggested by Limão and Maggi, 2013) that countries decide to cooperate in lines for which there is more variability. We leave this point though for further research and we focus our analysis on bound lines only, since our theoretical model is one on cooperative tariffs. 
Figure 4a: Percentage of lines with tariff increases, by level of water

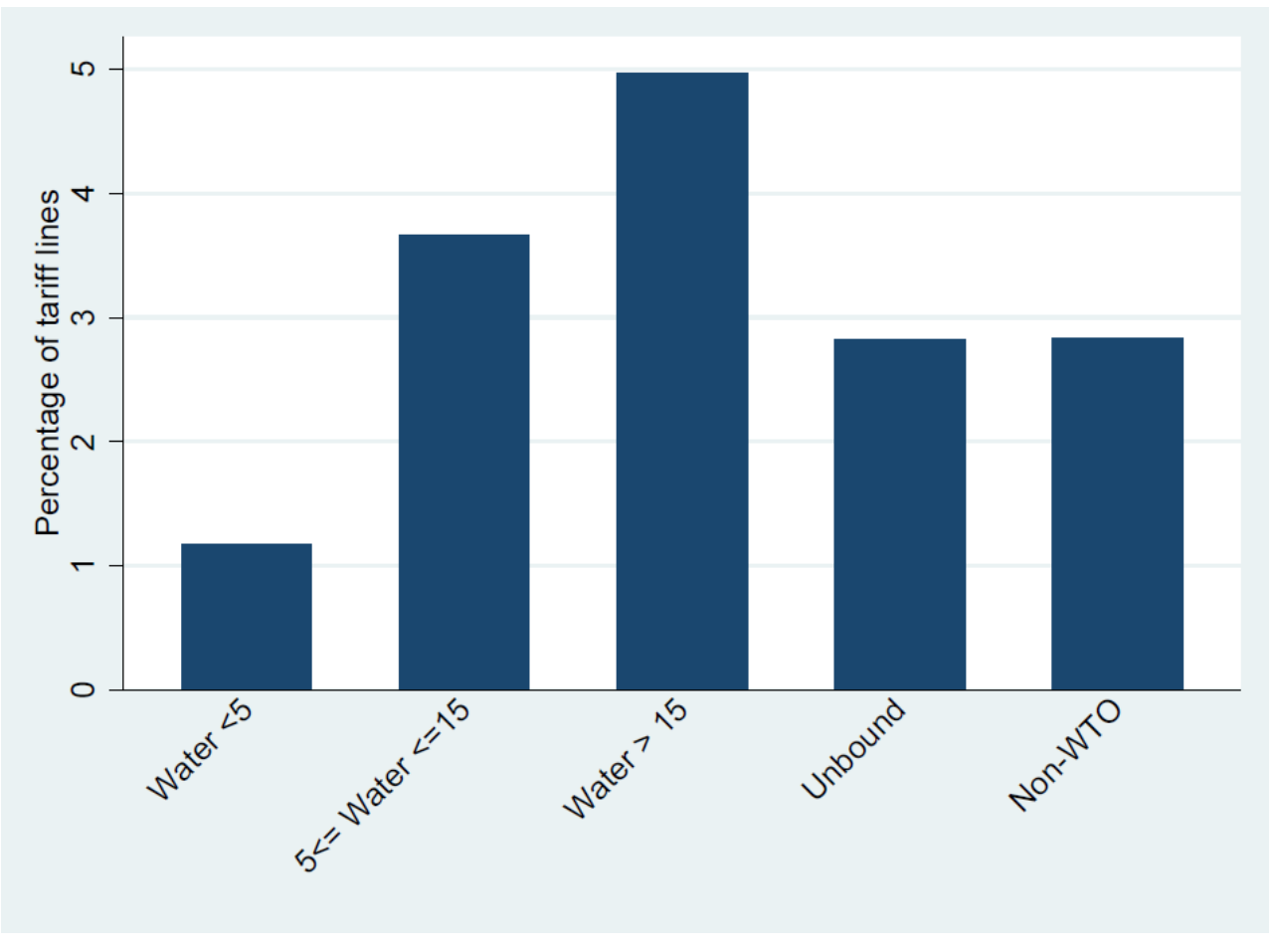

Figure 4b. Average size of the tariff increase, by level of water

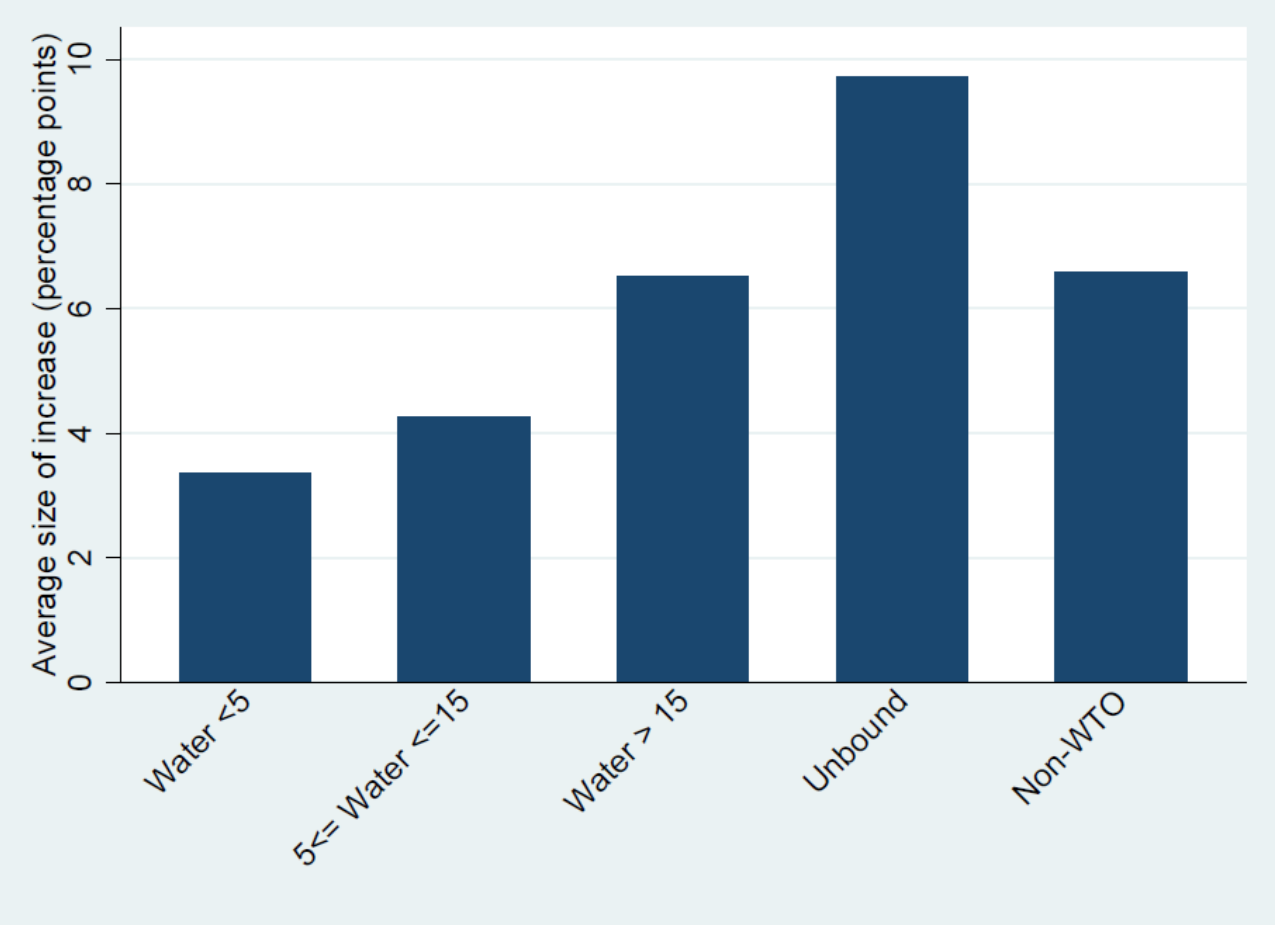

Note: The samples of the above graphs include those country-product pairs for which we have information on tariff change, bound status and lagged water in at least one of the years between 1997 and 2011. 
In figure 5 we report the percentage of tariff increases and the average size of the increases across years. Figure 5.a shows a certain tendency for an increasingly stable trade policy worldwide. Focussing on G-20 countries, Figure 5.b shows a significant increase in the use of tariffs in periods of economic crisis. ${ }^{14}$ In particular, the graph shows a peak in the number of tariff increases during the 1997 crisis. After the 1997 crisis, the average size of the tariff increases also peaked. A peak in the average size of MFN applied tariff increases is also observed in correspondence of the 2008 crisis. This suggests that tariff changes may be in part a response to specific economic conditions. ${ }^{15}$ We will control for the role of the business cycle in determining tariff changes in our regressions.

\section{Figure 5. Percentage of lines with tariff increases (left scale) and average size of the increases (right scale), 1997-2011}

\section{5.a. All countries}

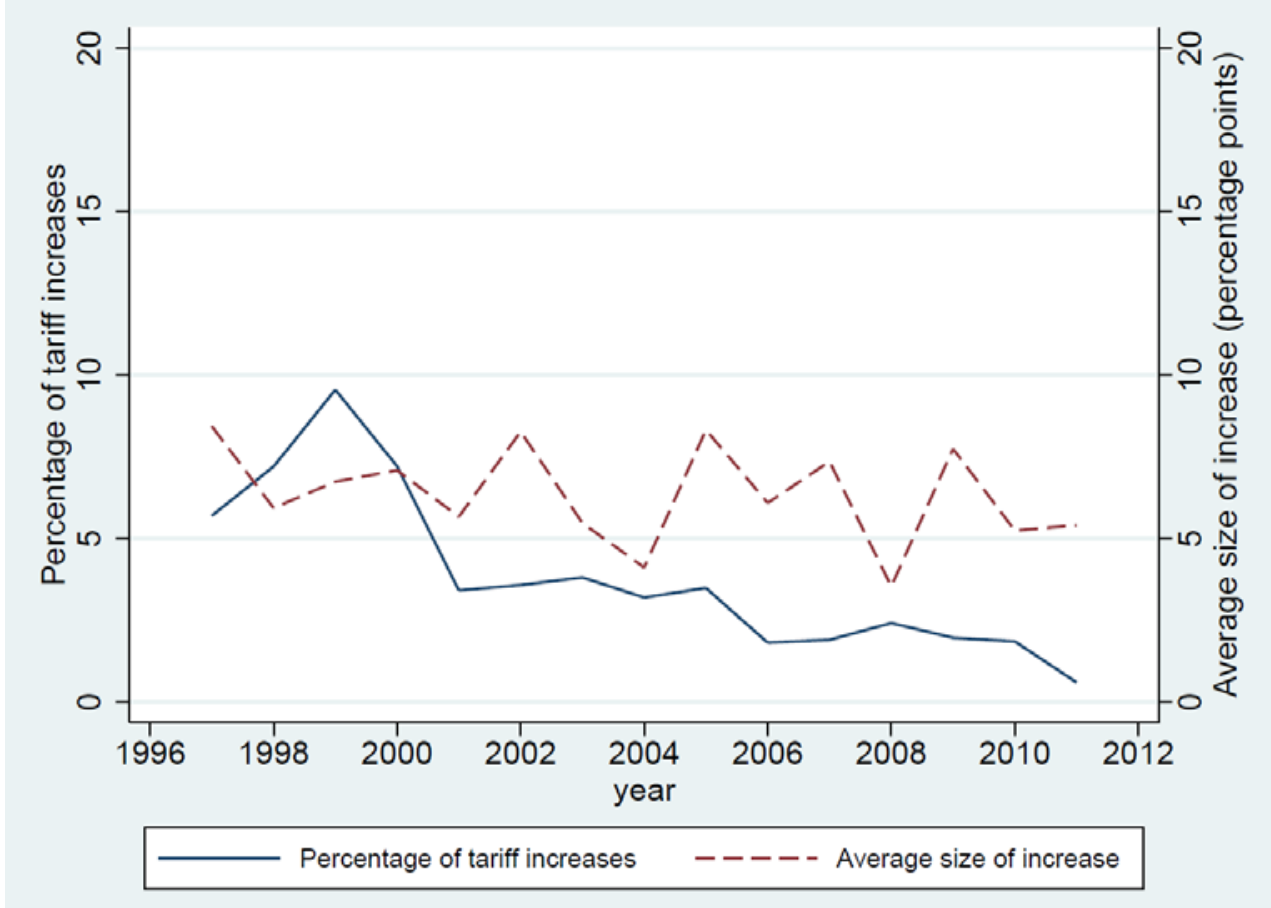

14 The peak in the percentage of tariff increases for G20 countries in 2004 is mainly due to Argentina. Between 2003 and 2004, the country increased its MFN applied tariffs for more than half of its tariff lines, in the majority of industries.

${ }^{15}$ The relationship between tariff changes and economic cycles is studied by Fugazza and Nicita (2011) and Rose (2013). The papers achieve opposite conclusions about whether trade policy is counter-cyclical or not. 


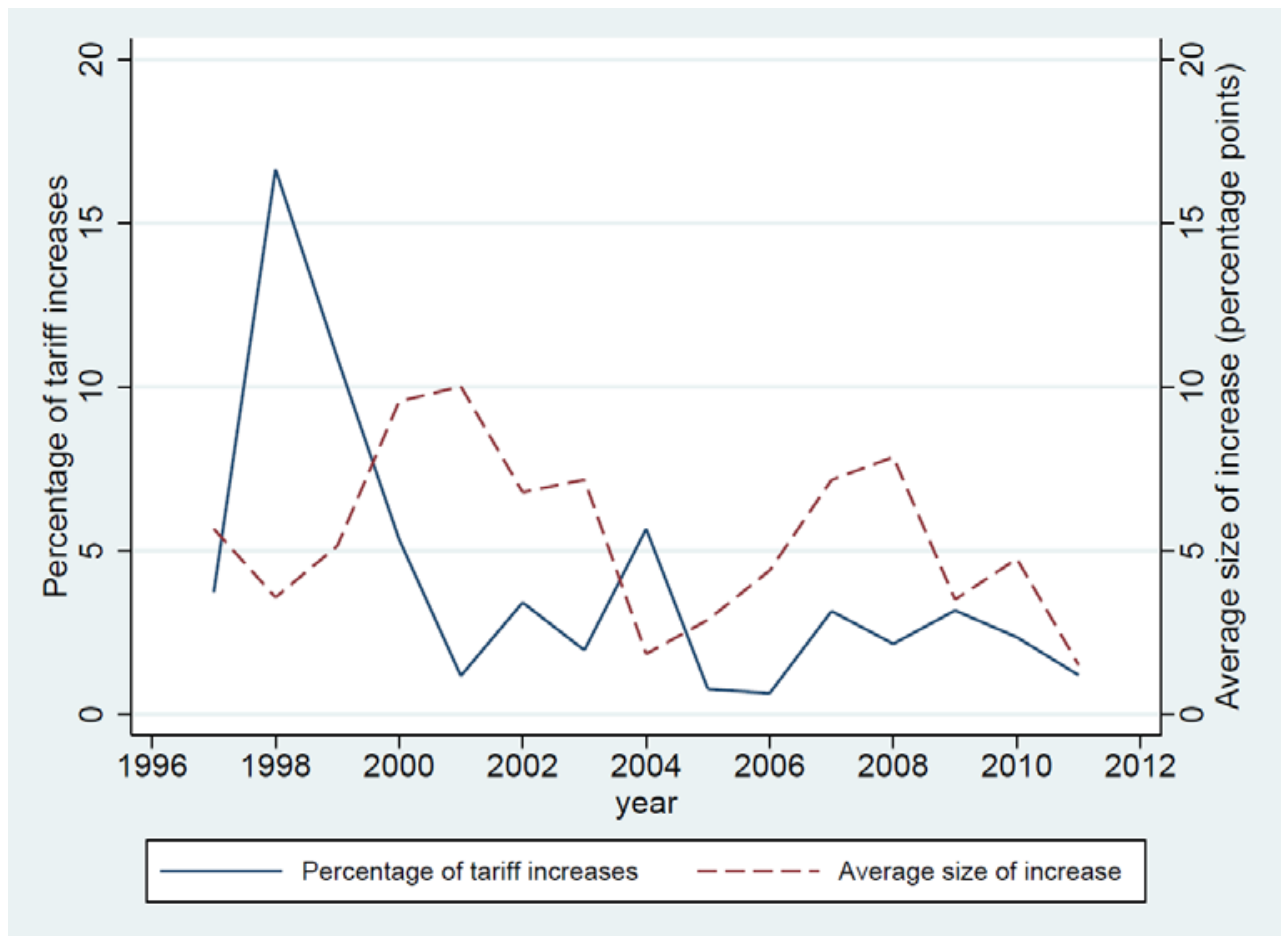

Note: The graphs have been obtained considering any available data on tariff changes (any available year-country-sector), for all countries and G20 countries, respectively. The percentage of tariff increases is obtained as the number of lines registering a tariff increase in year $t$, divided by the total number of lines for which we have information on tariffs in years $t$ 1 and $t$.

\section{An empirical model of trade policy uncertainty}

In order to identify the key determinants of MFN applied tariff changes, we rely on B\&S's theory of cooperative tariffs. The model's key predictions are that the gains from defection are higher if there is an unexpected surge of imports, as well as when export supply and import demand are inelastic. The model also predicts that the gains from cooperation decrease when the variance of imports declines. We interpret B\&S's predictions of an increase in gains from defection (or a decrease in gains from cooperation) as a higher probability of a tariff increase, and use the models' predictions to specify our empirical model. ${ }^{16}$

Then, we augment the B\&S model by adding a measure of trade policy flexibility determined by WTO commitments. The idea is that changing a tariff is costly (there are political costs to be paid because a tariff change always has redistribution effects, for example). Even more costly is increasing MFN applied tariffs above the bound rate. In fact, WTO rules define specific requirements to be fulfilled for a safeguard measure to be introduced. Hence, for a given magnitude of the import surge,

\footnotetext{
${ }^{16}$ In doing this, we follow Bown and Crowley (2013).
} 
governments will increase their tariff only if they have the margin of flexibility to increase it to the new optimal level.

In particular, we estimate the following baseline equation:

$$
\begin{aligned}
\operatorname{Prob}\left(d t_{c k t}=1\right)= & \\
=\beta_{0}+ & \beta_{1} \Delta(\text { Share_Imports })_{c k t-1}+\beta_{2} S d(\Delta \text { Share_Imports })_{c k}+ \\
& +\beta_{3} \text { Share_Imports }_{c k}+ \\
& +\beta_{4} \text { WTOflexibility }_{c k t}+\beta_{5} \boldsymbol{X}_{c t}+\gamma_{c}+\gamma_{k}+\gamma_{t}+\varepsilon_{c k t}
\end{aligned}
$$

where $d t_{c k t}$ measures a trade policy change implemented by country $c$, on sector $k$ at time $t$. In our estimations this is a dummy variable equal to one when a tariff increases relative to the previous year and zero otherwise. We, therefore, estimate a logit model to examine the determinants of this probability. ${ }^{17}$

\section{B\&S variables}

$\Delta(\text { Share_Imports })_{c k t-1}$ is a proxy for the unexpected import surge in the model. We consider a country's average share of world imports in sector $k$ as the expected import volume. Hence, we define an unexpected import surge at $t-1$ as an increase in a country's shares of world imports for $k$ between $t-2$ and $t-1$. An unexpected surge in imports, by increasing the tariff revenues under defection relative to trade co-operation, increases the incentive to defect. In these circumstances, an increase in cooperative tariffs, by reducing the expected volume of trade, will help to sustain cooperation. Therefore, we expect a positive estimate for the coefficient for the unexpected import growth, $\beta_{1}$.

The variable $S d(\Delta \text { Share_Imports })_{c k}$ is the standard deviation of unexpected import growth. B\&S theoretical model shows that the gains from co-operation increase with the variance of imports. Hence, conditional on an import surge of a certain magnitude, the increase in a tariff for a certain product is more likely the lower is the cross-sectional variance of imports, that is, in sectors where unexpected import surges are less common. Therefore, we expect a negative estimate for the coefficient for the variance of imports, $\beta_{2}$.

\footnotetext{
${ }^{17}$ We also test the robustness of our results to the inclusion of the interaction term between change in imports and market power. Although the overall marginal effect of import growth on the probability of a tariff increase had the correct sign, the interaction term on its own did not. For this reason, and because the exact specification of the non-linear effect of the level of imports on the probability of a tariff increase is not driven by the theory, we limit to simply control for these two variables' average effects, without imposing a specific functional form.
} 
Share_Imports ${ }_{c k}$ is the average over time of a country's share of world imports in a given sector. This is a proxy for market power, which we use instead of the inverse of the sum of export supply and import demand elasticities, since elasticity data are only available for a subset of 16 countries (Broda, Greenfield, and Weinstein, 2006; Broda, Limão, and Weinstein, 2008). ${ }^{18}$ B\&S's model predicts that tariffs are more likely to increase if export supply and import demand are inelastic. These elasticities reflect the extent to which countries detect a defection and respond to it. Clearly, the lower a country's response to defection, the higher will be the gain from its trading partner when defecting. Accordingly, the B\&S model predicts that an unexpected import surge will only affect the incentive to defect (and therefore trigger a tariff increase) if export supply and import demand are relatively inelastic. In fact, for highly competitive sectors, the inverse of the sum of export supply and import demand is likely to be low, thus implying a small incentive to defect. In contrast, for sectors characterised by strong market power, the incentive to defect will be high. We expect a positive estimate for the coefficient for the degree of market power, $\beta_{3}$.

\section{Measures of trade policy flexibility}

WTOflexibility denotes the margin of flexibility that countries have in setting their MFN applied tariff. One way we measure the extent of this flexibility is by calculating the difference between the bound $\left(\mathrm{T}^{\mathrm{B}}\right)$ and the MFN applied tariff rate $(\mathrm{T})$, the so-called water in the tariff.

However, as noted by Foletti et al. (2011), water may provide an overestimation of the extent of available flexibility, because some bound rates may be above the prohibitive tariff levels. To control for this possibility, we also measure WTO flexibility in terms of effective water, that is the difference between the bound and the applied rates, when the bound rate is below the prohibitive tariff $\left(\mathrm{T}^{\mathrm{P}}\right)$, and as the difference between the prohibitive and the applied tariff rate if the bound rate is above the prohibitive tariff. Like in Foletti et al. we define the prohibitive tariff as $\mathrm{T}+(1+\mathrm{T}) / \eta_{c k}^{m}$, where $\eta_{c k}^{m}$ indicate the import demand elasticity for country c and sector k. We calculate the prohibitive tariff using estimates of import demand elasticity at the 6-digit level from Kee, Nicita and Olarreaga (2008). We expect the estimate for $\beta_{4}$ to be positive.

We also allow for a more general specification of WTO flexibility, in which the three determinants of the level of water enter the equation separately, in their logarithmic form. This specification presents

${ }^{18}$ In particular, Broda, Limão and Weinstein (2008) provide estimates of export supply elasticities for the United States and 15 other countries. Elasticities are estimated using mainly pre-accession data. Broda, Greenfield, and Weinstein (2006) provided import demand elasticities for 73 countries. The data are available at http://www.columbia.edu/ dew35/TradeElasticities/TradeElasticities.html (last access: December 2014). 
two advantages: first, it allows interpreting the regressions coefficients as elasticities, and, second, it allows us to focus our analysis on the bound rate. This is the policy variable that negotiators negotiate about in a trade agreement.

In formulas, our measures of WTO flexibility are as follows:

$$
\text { WTO flexibility } \text { ckt }=\left\{\begin{array}{l}
\text { water }_{c k t} \equiv T_{c k t}^{B}-T_{c k t-1} \\
\text { effective } \text { water }_{c k t} \equiv \min \left(T_{c k t}^{B}-T_{c k t-1} ; T_{c k t}^{P}-T_{c k t-1}\right) \\
\text { aln }\left(1+T_{c k t}^{B}\right)-\mathrm{b} \ln \left(1+T_{c k t-1}\right)+\operatorname{cln}\left(1+T_{c k t}^{P}\right)
\end{array}\right.
$$

Finally, $\mathbf{X}$ is a vector of economic and institutional variables that we explain in detail in section 5, and $\gamma_{c}, \gamma_{k}, \gamma_{t}$ represent fixed effects controlling for all factors that are country, sector or time specific, respectively. ${ }^{19}$

\section{Empirical results}

The existing literature only finds weak evidence of an influence of WTO membership on trade policy. Rose (2004) finds no effect of WTO membership on the level of tariffs, while Cadot et al. (2010) find a weak effect of WTO membership on the volatility of agricultural protection. In general, the role of the WTO in determining trade policy is captured by a dummy variable indicating WTO membership. Therefore, these studies neglect that commitments under the WTO are not rigid, but flexible, and that they set tariff ceiling rather than tariff levels.

We depart from the existing literature by taking into account that the degree of trade policy flexibility varies. In particular, we consider variation of trade policy flexibility not only across countries, but also across sectors and over time. We construct a database of the binding rate in force over the period 1996-2011 and use it to estimate the impact of binding a line under the WTO on the risk of trade policy reversal.

${ }^{19}$ Note that this is the most disaggregated level of fixed effects for which we could use a logit. Country-sector 4 digit fixed effects cannot be implemented because STATA does not allow for so many fixed effects. Country-sector 4 digit fixed effects can only be included in a linear probability model (using the commands areg or reg2hdfe). In Appendix E, we report the results using country-year and country-sector 4 digit fixed effects for the linear probability model estimations. Results are robust to this specification. We also used the logistic model for rare events (STATA command relogit, which implements the procedure suggested by King and Zeng, 2001). Results, which are available upon request, are robust to this specification. However, this requires an even more aggregated set of fixed effects, at the 2 digit. Therefore, we opted to use logit as our baseline and allow for more disaggregated control variables. 
In Table 4, we report the results of our estimation of the B\&S model for the determination of changes in MFN applied tariffs. Column 1 shows that the model works reasonably well in explaining tariff changes. All B\&S variables are significant and show the expected sign. Tariff increases are more likely when there are unexpected surges in imports, in sectors where market power is high and where import surges are uncommon. Results are robust to the use of time-varying country fixed effects (column 2) and country-industry fixed effects (column 3). ${ }^{20}$ To make sure that our results are not only driven by tariff change dynamics in small countries, in columns 4 to 6 we also run these regressions for the subsample of G-20 countries. The results are largely consistent with those we find for the full sample.

Table 4. Verifying Bagwell and Staiger's model of varying MFN applied tariffs

\begin{tabular}{|c|c|c|c|c|c|c|}
\hline & \multicolumn{6}{|c|}{ Dependent variable: $1=$ MFN applied tariff increase } \\
\hline & \multicolumn{3}{|c|}{ Full sample } & \multicolumn{3}{|c|}{ G-20 } \\
\hline & $\begin{array}{c}\text { Logit } \\
(1)\end{array}$ & $\begin{array}{c}\text { Logit } \\
(2)\end{array}$ & $\begin{array}{c}\text { LPM } \\
(3)\end{array}$ & $\begin{array}{c}\text { Logit } \\
(4)\end{array}$ & $\begin{array}{c}\text { Logit } \\
(5)\end{array}$ & $\begin{array}{c}\text { LPM } \\
(6) \\
\end{array}$ \\
\hline$\Delta(\text { Share of imports })_{\mathrm{ckt}-1}$ & $\begin{array}{c}1.025^{* * *} \\
{[0.219]}\end{array}$ & $\begin{array}{c}0.472 * \\
{[0.256]}\end{array}$ & $\begin{array}{c}0.006^{\#} \\
{[0.004]}\end{array}$ & $\begin{array}{c}1.008^{* * *} \\
{[0.265]}\end{array}$ & $\begin{array}{c}0.220 \\
{[0.291]}\end{array}$ & $\begin{array}{c}0.002 \\
{[0.005]}\end{array}$ \\
\hline Std. Dev. of $\Delta$ (Share of imports $)_{\mathrm{ck}}$ & $\begin{array}{c}-0.907 * * * \\
{[0.259]}\end{array}$ & $\begin{array}{l}-0.478^{\#} \\
{[0.324]}\end{array}$ & $\begin{array}{c}-0.037 * * * \\
{[0.005]}\end{array}$ & $\begin{array}{c}-1.229 * * * \\
{[0.335]}\end{array}$ & $\begin{array}{c}-0.871^{* *} \\
{[0.403]}\end{array}$ & $\begin{array}{c}-0.060^{* * *} \\
{[0.009]}\end{array}$ \\
\hline Share of imports ${ }_{\mathrm{ck}}$ & $\begin{array}{c}1.600^{* * *} \\
{[0.162]}\end{array}$ & $\begin{array}{c}1.893^{* * *} \\
{[0.183]}\end{array}$ & $\begin{array}{c}0.028 * * * \\
{[0.004]}\end{array}$ & $\begin{array}{c}1.694 * * * \\
{[0.173]}\end{array}$ & $\begin{array}{c}1.865^{* * *} \\
{[0.195]}\end{array}$ & $\begin{array}{c}0.032 * * * \\
{[0.004]}\end{array}$ \\
\hline Observations & $4,052,298$ & $3,087,355$ & $4,226,468$ & 860,123 & 767,560 & 860,123 \\
\hline Year FE & YES & NO & NO & YES & NO & NO \\
\hline Country FE & YES & NO & NO & YES & NO & NO \\
\hline Sector4dig FE & YES & YES & NO & YES & YES & NO \\
\hline CountrySector4dig FE & NO & NO & YES & NO & NO & YES \\
\hline CountryYear FE & NO & YES & YES & NO & YES & YES \\
\hline Pseudo-R ${ }^{2}$ & 0.224 & 0.480 & 0.478 & 0.245 & 0.444 & 0.420 \\
\hline Log-Likelihood & -460230 & -288954 & - & -105755 & -75715 & - \\
\hline
\end{tabular}

Notes: The samples only include bound lines. ${ }^{* * *},{ }^{* *},{ }^{*},{ }^{*}$ indicate significance at $1,5,10,15$ percent. Robust standard errors in parentheses, clustered by country-industry (4 digit).

In Table 5, we consider the role of WTO flexibility as a determinant of trade policy uncertainty. We consistently find a positive and statistically significant coefficient for the level of water (whether nominal or adjusted to account for the prohibitive tariff) and that the higher the bound rate, the higher is the probability of a tariff increase. The results reported in this table are those obtained from the logit

${ }^{20}$ Note in column 3 that we estimate a Linear Probability (LPM) model. This is because the logit model cannot be run due to the large number of dummy variables. 
model using year, country and sector fixed effects. We choose this as preferred estimation strategy because it entails the most disaggregated set of fixed effects we can use with the logit model. Our estimates using LPM with country-year and country-sector fixed effects are provided in appendix E. They support our baseline estimates.

Table 5: Augmenting B\&S model to account for WTO flexibility (logit)

\begin{tabular}{|c|c|c|c|c|c|c|}
\hline & \multicolumn{6}{|c|}{ Dependent variable: $1=$ MFN applied tariff increase } \\
\hline & \multicolumn{3}{|c|}{ Full sample } & \multicolumn{3}{|c|}{ G20 } \\
\hline & $(1)$ & $(2)$ & (3) & (4) & (5) & (6) \\
\hline \multicolumn{7}{|l|}{ WTO flexibility } \\
\hline Ln $(1+\text { Bound rate })_{\mathrm{ckt}}$ & $\begin{array}{c}2.353 * * * \\
{[0.097]}\end{array}$ & & & $\begin{array}{c}2.301^{* * *} \\
{[0.170]}\end{array}$ & & \\
\hline Ln $(1+\text { Prohibitive tariff })_{\mathrm{ckt}}$ & $\begin{array}{c}0.346 * * * \\
{[0.009]}\end{array}$ & & & $\begin{array}{c}0.237 * * * \\
{[0.013]}\end{array}$ & & \\
\hline Ln (1 + MFN applied tariff $)_{\text {ckt-1 }}$ & $\begin{array}{c}-7.785^{* * *} \\
{[0.200]}\end{array}$ & & & $\begin{array}{c}-5.733^{* * *} \\
{[0.443]}\end{array}$ & & \\
\hline Water $_{\text {ckt }}$ & & $\begin{array}{c}1.423^{* * *} \\
{[0.052]}\end{array}$ & & & $\begin{array}{c}1.289 * * * \\
{[0.093]}\end{array}$ & \\
\hline Effective water $_{\text {ckt }}$ & & & $\begin{array}{c}1.873^{* * *} \\
{[0.054]}\end{array}$ & & & $\begin{array}{c}1.798^{* * *} \\
{[0.106]}\end{array}$ \\
\hline \multicolumn{7}{|l|}{ Bagwell and Staiger's model } \\
\hline$\Delta(\text { Share of imports })_{\mathrm{ckt}-1}$ & $\begin{array}{c}1.072 * * * \\
{[0.229]}\end{array}$ & $\begin{array}{c}1.079 * * * \\
{[0.221]}\end{array}$ & $\begin{array}{c}1.123 * * * \\
{[0.225]}\end{array}$ & $\begin{array}{c}1.019 * * * \\
{[0.272]}\end{array}$ & $\begin{array}{c}1.060 * * * \\
{[0.268]}\end{array}$ & $\begin{array}{c}1.088^{* * *} \\
{[0.270]}\end{array}$ \\
\hline Std. Dev. of $\Delta$ (Share imports)ck & $\begin{array}{c}-1.060 * * * \\
{[0.297]}\end{array}$ & $\begin{array}{c}-0.927 * * * \\
{[0.271]}\end{array}$ & $\begin{array}{c}-1.020 * * * \\
{[0.278]}\end{array}$ & $\begin{array}{c}-1.102 * * * \\
{[0.364]}\end{array}$ & $\begin{array}{c}-1.272 * * * \\
{[0.347]}\end{array}$ & $\begin{array}{c}-1.265 * * * \\
{[0.356]}\end{array}$ \\
\hline Share of imports $\mathrm{ck}_{\mathrm{k}}$ & $\begin{array}{c}1.328 * * * \\
{[0.188]}\end{array}$ & $\begin{array}{c}1.650 * * * \\
{[0.170]}\end{array}$ & $\begin{array}{c}1.616^{* * *} \\
{[0.176]}\end{array}$ & $\begin{array}{c}1.547 * * * \\
{[0.194]}\end{array}$ & $\begin{array}{c}1.732^{* * *} \\
{[0.181]}\end{array}$ & $\begin{array}{c}1.701^{* * *} \\
{[0.187]}\end{array}$ \\
\hline Observations & $3,908,940$ & $4,008,914$ & $3,908,940$ & 836,530 & 858,049 & 836,530 \\
\hline Year FE & YES & YES & YES & YES & YES & YES \\
\hline Country FE & YES & YES & YES & YES & YES & YES \\
\hline Sector4dig FE & YES & YES & YES & YES & YES & YES \\
\hline Pseudo- $\mathrm{R}^{2}$ & 0.241 & 0.230 & 0.230 & 0.255 & 0.250 & 0.250 \\
\hline Log-Likelihood & -438918 & -454475 & -445129 & -102024 & -104713 & -102642 \\
\hline
\end{tabular}

Notes: The samples only include bound lines. ${ }^{* * *},{ }^{* *},{ }^{*}$, indicate significance at $1,5,10$ percent. Robust standard errors in parentheses, clustered by country-industry (4 digit). 


\section{Extending the model to economic, policy and institutional determinants of trade policy}

This theoretically founded empirical model of trade policy uncertainty provides a novel approach to analyse long-standing questions. For instance: is protectionism counter-cyclical? Are multilateral and preferential liberalization substitute or complements? Is there a quantifiable gain from transparency? To address these questions, we include in our model a set of additional variables that economic theory and conventional wisdom indicate as potentially significant determinant of protectionist behaviours.

First, we include the (logarithm) of GDP level $(\ln (G D P))$. A country's propensity to use MFN applied tariffs in response to an import surge is likely to depend on its GDP level. Rich economies may recur to subsidies rather than MFN applied tariffs to respond to a negative economic shock, while this option may not be available for less wealthy economies.

Second, we control for the economic cycle with GDP growth. The political economy literature indicates that the average level of protection tends to rise during economic recessions. This is because, for example, governments face increasing pressure to secure domestic market for domestic firms (Cassing, McKeown, and Ochs, 1986) or to counter incentives to manipulate the terms-of-trade (Bagwell and Staiger, 2003). The empirical evidence in general supports this claim (Bohara and Kaempfer, 1991; Grilli, 1988; Knetter and Prusa, 2003). However, a recent paper by Rose (2013) finds that protectionism is no longer counter-cyclical in the post-war period.

Third, we control for a country's participation in Preferential Trade Agreements (PTAs). Participation in PTAs may foster or hinder the incentive to increase MFN applied tariffs. Indeed, a long standing debate in the trade literature explores whether PTAs are complements or substitutes to multilateral agreements. If trade diversion resulting from a PTA is costly, a PTA will provide governments with an incentive to keep MFN applied tariffs low (Bagwell and Staiger 1999b; Bond, Raymond, and Syropoulos, 2004; Freund, 2000). However, if PTAs go beyond co-operation on trade tariffs, member countries will have an incentive to keep their external tariff high. This is because higher external tariffs provide PTA partners a greater margin of trade preference in accessing each other's market and this, in turn, will support PTA member countries' effort to subscribe (and maintain) their nontrade concessions (hereafter, we will refer to this as to the preference erosion argument of Limão, 2007).

In our context, given a certain import surge, PTAs will be more or less likely to increase external tariffs depending on whether preference erosion or trade diversion considerations prevail. As a measure for PTA, we use the average depth of the PTAs that a country has signed (PTA_depth). The depth of a PTA is constructed from the WTO database on PTA contents and is defined as the count of 
provisions covered in the agreement out of the 52 policy areas mapped, several of which are provisions that fall outside the current scope of the WTO agreements (such, for example, labour standards, migration policy, and security). The larger the number of provisions covered by a PTA, the stronger the preference erosion argument for "substitutability" between multilateral and preferential liberalization relative to the trade diversion argument for "complementarity." Therefore, we expect a positive coefficient for our variable of PTA depth.

In addition, we take into account that the effect of a PTA on the likelihood to raise tariffs may differ between a free trade area (FTA) and a customs union (CU). The literature suggests that CU are more likely than FTA to increase their external tariffs (or have a lower incentive to keep low tariffs), because CU can exploit their joint market power when setting their common external tariff (Bagwell and Staiger 1999b; Bond and Syropoulos, 1996; Freund, 2000; Ornelas, 2007). Following Estevadeordal, Freund and Ornelas (2008), to determine whether the type of the agreement matters, we interact the variable PTA_depth with a dummy variable which equals one if the PTA is a CU. The theoretical argument that $\mathrm{CU}$ are more likely to set higher external tariffs suggests that estimated coefficient for the interaction term PTA_depth*CU should be positive. However, since economic shocks may not affect all countries in a $\mathrm{CU}$, it may result to be relatively more costly to change external tariffs in a CU than in an FTA (Horn, Maggi and Staiger, 2010). The overall effect of a CU on the likelihood of a tariff increase is, therefore, not unambiguously predictable.

Finally, we include the dummy variable $T P R_{t-1}$, which equals one if the country was under trade policy review at the WTO at time $t-1$ (we use the lag of the TPR variables because it takes approximately one year to issue a TPR report). One of the functions of the WTO is to review, for the purpose of transparency, the trade policies of its Members through the WTO's Trade Policy Review Mechanism (TPRM). ${ }^{21}$ The TPRM aims at improving Members' adherence to rules, disciplines and commitments by providing an opportunity to understand how WTO commitments are being implemented. This review process focusses on providing feedbacks on a WTO country's trade policy and not assessing whether a country is in breach of commitments. Under WTO rules, the four largest countries are reviewed every two years, the subsequent 16 every four years and the rest of the Members every six years. One may expect that this review process may help WTO Members to reinforce their effort to implement WTO commitments and work as a deterrent for governments to increase tariffs. A negative coefficient of this variable would point in this direction.

In sum, our vector of control variables is:

$$
\boldsymbol{X}=\left[\ln \left(G D P_{c t-1}\right), G D P \text { growth }_{c t-1}, P T A \text { depth }_{c t}, P T A \text { depth }_{c t} * C U_{c t}, C U_{c t}, T P R_{c t-1}\right]
$$

\footnotetext{
${ }^{21}$ See Article III (4), Marrakesh Agreement establishing the WTO.
} 
In Table 6 we progressively include the economic, policy and institutional control variables discussed above. We find that low-income countries have a higher propensity to increase MFN applied tariffs than rich countries. This is coherent with the view that more advanced economies have means other than MFN applied tariff changes (like, for example, subsidies) to face import surges, while small economies are on average more resource constrained and may have no other choice than protect their industries from import competition using tariffs. Second, we find that the likelihood of trade policy reversals increases in periods of economic slumps, which support the view that trade policy is counter-cyclical.

Turning to the debate about the relationship between multilateral or preferential liberalization, our results suggest that they may be "substitutes." We estimate a positive coefficient on our variable for deep preferential trade agreements. That is, PTA Members are more likely to change MFN applied tariffs that affect trade with third countries when their preferential agreement is deeper. However, this pattern is reversed in CU. Finally, we estimate a significant and negative coefficient for the variable TPR. That is, when a Member's trade policy is under review at the WTO, the country is less likely to increase its MFN applied tariff than it would do otherwise.

We consistently find that the WTO flexibility is a significant determinant of the probability of a tariff increase. To estimate the contribution of WTO commitments to trade policy certainty, we assume that, in the absence of WTO commitments, the policy space is determined by the prohibitive tariff. Hence, we use the model of table 6 column 3, to estimate the average predicted probability when the bound increases up to the prohibitive tariffs and compare it with the original average predicted probability by the model. We use the difference between these two predicted probabilities to measure the contribution of WTO to trade policy predictability. We estimate that WTO commitments reduce the probability of a tariff increase by 9.5 percentage points. We use a similar procedure to calculate the impact of WTO on the basis of our estimates for water and effective water (columns 4 and 5). We obtain that WTO commitments reduce the probability of a tariff increase by 11.4 and 16.4 percentage points, for the models in column 4 and 5 , respectively. ${ }^{22}$

\footnotetext{
${ }^{22}$ Appendix F reports the marginal effects of the estimates in table 6.
} 
Table 6: An empirical model of trade policy uncertainty (logit)

Dependent variable: $1=$ MFN applied tariff increase

\begin{tabular}{|c|c|c|c|c|c|c|c|}
\hline \multicolumn{5}{|c|}{ Full sample } & \multicolumn{3}{|c|}{ G20 } \\
\hline$(1)$ & $(2)$ & (3) & (4) & (5) & $(6)$ & $(7)$ & $(8)$ \\
\hline $\begin{array}{c}2.353^{* * *} \\
{[0.097]}\end{array}$ & $\begin{array}{c}2.822 * * * \\
{[0.114]}\end{array}$ & $\begin{array}{c}2.822 * * * \\
{[0.114]}\end{array}$ & & & $\begin{array}{c}2.490 * * * \\
{[0.197]}\end{array}$ & & \\
\hline $\begin{array}{c}0.345^{* * *} \\
{[0.009]}\end{array}$ & $\begin{array}{c}0.325^{* * * *} \\
{[0.009]}\end{array}$ & $\begin{array}{c}0.325^{* * *} \\
{[0.009]}\end{array}$ & & & $\begin{array}{c}0.241^{* * *} \\
{[0.014]}\end{array}$ & & \\
\hline $\begin{array}{c}-7.737 * * * \\
{[0.200]}\end{array}$ & $\begin{array}{c}-7.520 * * * \\
{[0.236]}\end{array}$ & $\begin{array}{c}-7.509 * * * \\
{[0.235]}\end{array}$ & & & $\begin{array}{c}-6.322 * * * \\
{[0.564]}\end{array}$ & & \\
\hline \multirow{2}{*}[0.200]{} & & & $\begin{array}{c}1.662 * * * \\
{[0.062]}\end{array}$ & & & $\begin{array}{c}1.442^{* * *} \\
{[0.107]}\end{array}$ & \\
\hline & & & & $\begin{array}{c}2.125^{* * *} \\
{[0.063]}\end{array}$ & & & $\begin{array}{c}2.036^{* * *} \\
{[0.118]}\end{array}$ \\
\hline $\begin{array}{c}1.690 * * * \\
{[0.232]}\end{array}$ & $\begin{array}{c}1.692 * * * \\
{[0.238]}\end{array}$ & $\begin{array}{c}1.600 * * * \\
{[0.238]}\end{array}$ & $\begin{array}{c}1.563 * * * \\
{[0.232]}\end{array}$ & $\begin{array}{c}1.638 * * * \\
{[0.237]}\end{array}$ & $\begin{array}{c}0.567 * \\
{[0.292]}\end{array}$ & $\begin{array}{c}0.625^{* *} \\
{[0.288]}\end{array}$ & $\begin{array}{c}0.671^{* *} \\
{[0.295]}\end{array}$ \\
\hline$-1.302^{* * *}$ & $-1.390 * * *$ & $-1.362 * * *$ & $-1.187^{* * *}$ & $-1.331^{* * *}$ & $-0.930 * *$ & $-1.093^{* * *}$ & $-1.168^{* * *}$ \\
\hline [0.308] & [0.309] & [0.308] & [0.295] & [0.302] & [0.383] & [0.371] & [0.383] \\
\hline $1.383 * * *$ & $1.389 * * *$ & $1.386 * * *$ & $1.679 * * *$ & $1.646 * * *$ & $1.569 * * *$ & $1.775^{* * *}$ & $1.743^{* * *}$ \\
\hline [0.190] & [0.190] & [0.190] & [0.177] & [0.181] & [0.203] & [0.189] & [0.195] \\
\hline
\end{tabular}


Table 6: An empirical model of trade policy uncertainty (logit) - continued

\begin{tabular}{|c|c|c|c|c|c|c|c|c|}
\hline & \multicolumn{8}{|c|}{ Dependent variable: $1=$ MFN applied tariff increase } \\
\hline & \multicolumn{5}{|c|}{ Full sample } & \multicolumn{3}{|c|}{ G20 } \\
\hline & $(1)$ & $(2)$ & $(3)$ & $(4)$ & $(5)$ & $(6)$ & $(7)$ & $(8)$ \\
\hline \multicolumn{9}{|c|}{ Economic and Institutional variables } \\
\hline $\operatorname{Ln}(G D P)_{\mathrm{ct}}$ & $\begin{array}{c}-1.067 * * * \\
{[0.041]}\end{array}$ & $\begin{array}{c}-0.967 * * * \\
{[0.042]}\end{array}$ & $\begin{array}{c}-0.960 * * * \\
{[0.042]}\end{array}$ & $\begin{array}{c}-1.019 * * * \\
{[0.040]}\end{array}$ & $\begin{array}{c}-0.996 * * * \\
{[0.041]}\end{array}$ & $\begin{array}{c}-1.260 * * * \\
{[0.050]}\end{array}$ & $\begin{array}{c}-1.254^{* * *} \\
{[0.048]}\end{array}$ & $\begin{array}{c}-1.235 * * * \\
{[0.049]}\end{array}$ \\
\hline GDP growth $_{\mathrm{ct}}$ & $\begin{array}{c}-0.984 * * * \\
{[0.062]}\end{array}$ & $\begin{array}{c}-1.131 * * * \\
{[0.073]}\end{array}$ & $\begin{array}{c}-1.046 * * * \\
{[0.076]}\end{array}$ & $\begin{array}{c}-1.024 * * * \\
{[0.076]}\end{array}$ & $\begin{array}{c}-1.057 * * * \\
{[0.077]}\end{array}$ & $\begin{array}{c}-0.582 * * * \\
{[0.128]}\end{array}$ & $\begin{array}{c}-0.709 * * * \\
{[0.134]}\end{array}$ & $\begin{array}{c}-0.713 * * * \\
{[0.134]}\end{array}$ \\
\hline Average PTA depth $\mathrm{ct}_{\mathrm{t}}$ & & $\begin{array}{c}0.160 * * * \\
{[0.005]}\end{array}$ & $\begin{array}{c}0.161^{* * *} \\
{[0.005]}\end{array}$ & $\begin{array}{c}0.166^{* * * *} \\
{[0.005]}\end{array}$ & $\begin{array}{c}0.165^{* * *} \\
{[0.005]}\end{array}$ & $\begin{array}{c}0.225^{* * *} \\
{[0.008]}\end{array}$ & $\begin{array}{c}0.231^{* * *} \\
{[0.008]}\end{array}$ & $\begin{array}{c}0.228 * * * \\
{[0.008]}\end{array}$ \\
\hline Custom Union*(PTA depth) $)_{\mathrm{ct}}$ & & $\begin{array}{c}-0.011 \\
{[0.013]}\end{array}$ & $\begin{array}{c}-0.011 \\
{[0.013]}\end{array}$ & $\begin{array}{c}-0.002 \\
{[0.013]}\end{array}$ & $\begin{array}{c}-0.003 \\
{[0.013]}\end{array}$ & $\begin{array}{c}0.212^{* * *} \\
{[0.020]}\end{array}$ & $\begin{array}{c}0.198 * * * \\
{[0.019]}\end{array}$ & $\begin{array}{c}0.198 * * * \\
{[0.019]}\end{array}$ \\
\hline $\mathrm{CU}$ & & $\begin{array}{c}-1.855 * * * \\
{[0.180]}\end{array}$ & $\begin{array}{c}-1.834 * * * \\
{[0.181]}\end{array}$ & $\begin{array}{c}-2.062 * * * \\
{[0.175]}\end{array}$ & $\begin{array}{c}-1.943^{* * *} \\
{[0.179]}\end{array}$ & $\begin{array}{c}-1.334 * * * \\
{[0.242]}\end{array}$ & $\begin{array}{c}-1.403^{* * *} \\
{[0.242]}\end{array}$ & $\begin{array}{c}-1.394 * * * \\
{[0.242]}\end{array}$ \\
\hline Trade Policy Review ${ }_{\mathrm{ct}-1}$ & & & $\begin{array}{c}-0.285^{* * *} \\
{[0.024]}\end{array}$ & $\begin{array}{c}-0.296 * * * \\
{[0.024]}\end{array}$ & $\begin{array}{c}-0.289 * * * \\
{[0.025]}\end{array}$ & $\begin{array}{c}-0.724 * * * \\
{[0.060]}\end{array}$ & $\begin{array}{c}-0.743^{* * *} \\
{[0.060]}\end{array}$ & $\begin{array}{c}-0.718^{* * *} \\
{[0.060]}\end{array}$ \\
\hline Observations & $3,908,940$ & $3,208,097$ & $3,208,097$ & $3,289,876$ & $3,208,097$ & 793,236 & 813,493 & 793,236 \\
\hline Year FE & YES & YES & YES & YES & YES & YES & YES & YES \\
\hline Country FE & YES & YES & YES & YES & YES & YES & YES & YES \\
\hline Sector4dig FE & YES & YES & YES & YES & YES & YES & YES & YES \\
\hline Pseudo- $\mathrm{R}^{2}$ & 0.248 & 0.262 & 0.263 & 0.254 & 0.254 & 0.302 & 0.298 & 0.297 \\
\hline Log-likelihood & -434617 & -346177 & -345847 & -356858 & -349844 & -87579 & -89802 & -88133 \\
\hline
\end{tabular}

Note: The samples only include bound lines. ${ }^{* *},{ }^{* *}, *$, indicate significance at 1,5 , and 10 percent. Robust standard errors in parentheses, clustered by country-industry (4 digit). 


\section{Robustness tests}

Our baseline regressions support a number findings: they validate B\&S model of tariff changes; they support the claim that WTO commitments reduce the probability of a tariff increase as well as that tariff changes tend to be counter-cyclical, that the deeper the trade agreements the more likely that Member countries change MFN applied tariff and that the WTO also contribute to trade policy stability through its monitoring function.

\subsection{Redefining the dependent variable as size of the tariff increase}

In Table 7 we redefine the dependent variable as the size of the MFN applied tariff increases and reestimate the model as specified in Table 6 for the full sample and for the sample of countries member of the G-20. For this, we use a Tobit model censored at zero. These results are in line with those obtained in the baseline estimates. WTO commitments help reducing trade policy uncertainty. They help reduce not only the probability of a tariff increase, but also the expected size of the increase. There is also evidence that the WTO has a negative impact on the size of a tariff increase not only through its tariff commitments but also through its monitoring function. The size of the increase is also negatively correlated with the business cycle, and positively correlated with the depth of PTAs. 
Dependent Variable: Ln (1+size of the tariff increase), 0 otherwise

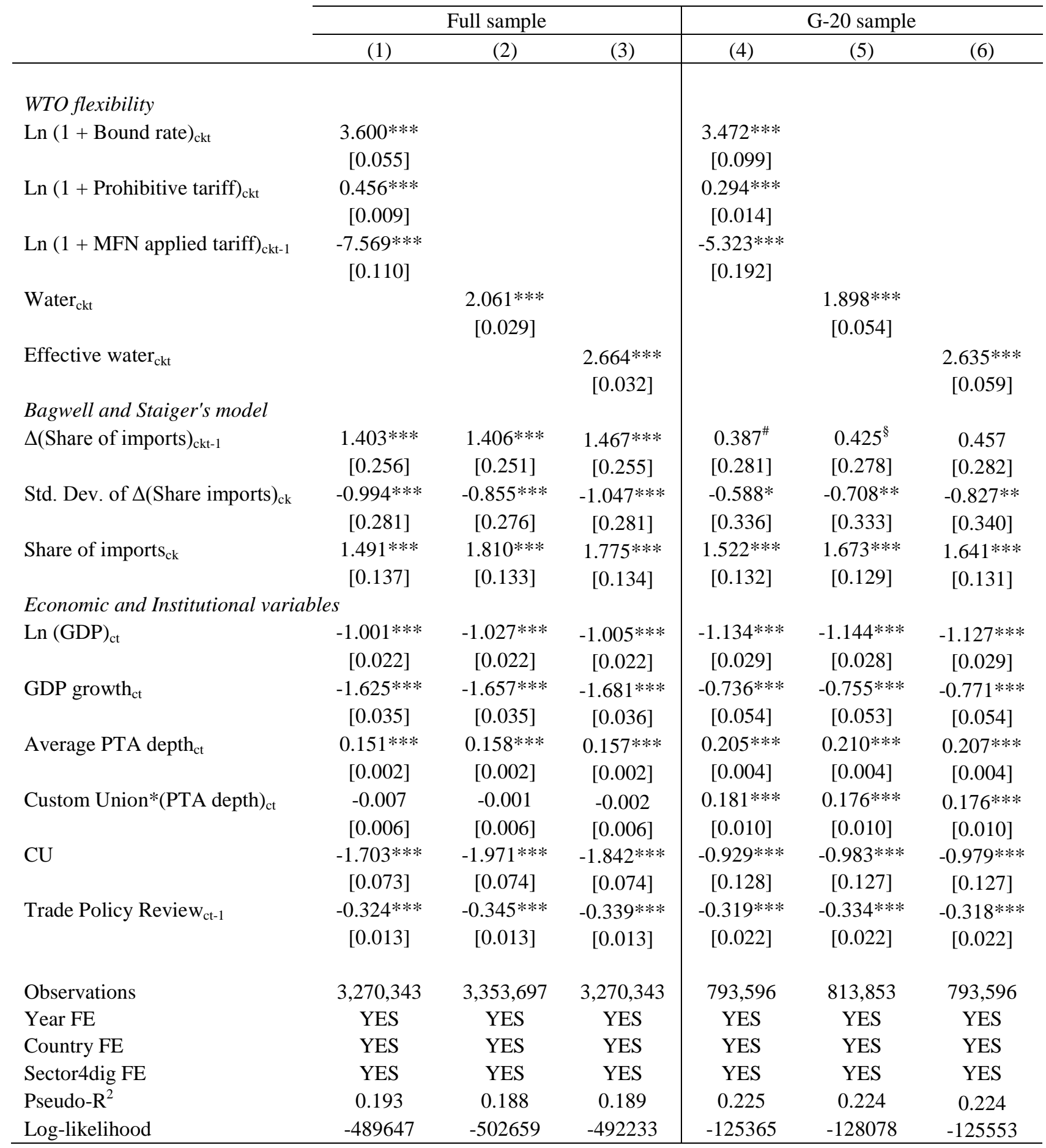

Note: All regressions include country, year, industry (4 digit) fixed effects. ***, **, *,\#,§ indicate significance at 1,5,10, 15, 25 percent level. Robust standard errors in parentheses. 


\subsection{Addressing endogeneity}

Bound rates may be endogenous. Governments may be more likely to set low bound rates in sectors where they expect less protectionist pressure (because, for example, that is a sector less likely to suffer from booms and busts; or because it is a declining sector). Fixed effects help address endogeneity due to omitted variable bias, but do not resolve potential reverse causality problems.

To address this issue, we estimate our model through instrumental variables. We use two instruments: pre-accession average imports and pre-accession average applied tariff. We focus on the sample of countries that joined the WTO in 2000 or thereafter. We use data for the period from 1996 to the accession date to build our instrumental variables.

The idea of using these instruments for the bound rate is largely determined by the work of Bagwell and Staiger (2011), who estimate WTO bound rates as a function of pre-accession tariffs and import quantity. However, trade theory provides also other justifications for the validity of these instruments.

These instruments are likely to be correlated with the bound rate. First, we expect average imports before accession (a proxy for market power) to be negatively correlated with the bound rate. According to Bagwell and Staiger (2011), the bound rate is a function of the ratio of prenegotiation import quantities to world prices. Therefore, we use as our instrument the average value of this ratio across pre-accession years, for each country-sector pair. ${ }^{22}$ Several models predict a negative correlation between market power before accession and the bound rate. The termsof-trade argument for trade agreements suggests that, since the international cost-shifting is higher in sectors with more market power, it is in these markets where relatively lower bound rates are required in order to protect exporters. Bagwell and Staiger (2011) find strong evidence in support of this theory for a sample of 16 countries that joined the WTO between 1995 and 2005. Similarly, when trade agreements aim at reducing uncertainty (Limão and Maggi, 2013), an exporter will be more likely to request an importing country to bind a certain import tariff, when the negative impact of a

${ }^{22}$ We follow a procedure similar to the one used by Bagwell and Staiger (2011) in order to obtain the ratio import quantity to prices. In particular, we obtain yearly world prices at the 2-digit HS level from COMTRADE (world prices are obtained by dividing total world value of trade by total world quantity in kg). We use this measure of prices to convert import values to quantities, which we then further divide by world prices. In this way we obtain values of the ratio of import quantity to prices, by country-sector-year. Then, for each country-sector, we average these values across pre-accession years, considering the exact year of accession of each country in our sample (the sectoral level of disaggregation of our instrument is still 6-digit, even though prices only vary at the 2-digit level). 
protectionist measure that the importing country may introduce in response to a shock is largest (that is when the importing country has more market power). A country's market power is a crucial factor in determining the level of the bound rate and the tariff overhang also in the model developed by Beshkar et al. (2012). In their model, a tariff overhang exists because governments value a margin of flexibility in being able to respond to economic shocks by using trade policy. However, if governments have private information about the magnitude of these shocks, large countries will have an incentive to over-report the actual magnitude of the shock and take advantage of their market power. Taking this into account, an optimal agreement limits the degree of flexibility of its member countries by decreasing the optimal bound rate (as well as the optimal tariff overhang) if the importing country's market power is higher.

Second, the level of the pre-accession applied tariff is likely to be positively correlated with the bound rate for two reasons. From a theoretical perspective, the terms-of-trade literature predicts a positive relationship between the magnitude of negotiated tariff cut $\left(\mathrm{T}^{\mathrm{B}}-\mathrm{T}^{\text {Pre-accession }}\right)$ and the level of imports, which implies a positive relationship between $\mathrm{T}^{\mathrm{B}}$ and $\mathrm{T}^{\text {Pre-accession }}$ by simply rearranging the terms of the relationship. Second, in practice, pre-existing applied tariff rates are often the starting point in the negotiations for accession to the WTO.

We focus on the sub-sample of countries that joined the WTO in 2000 or thereafter because our instruments (which are suggested by the prediction of a static model) are more appropriate for these countries than for the full sample. ${ }^{23}$ Indeed, as argued by Bagwell and Staiger (2011), the bound rate of these newly acceded countries is likely to reflect the predictions of a static model because, by the time these countries acceded the WTO, the pre-existing Members had already completed the implementation process of their commitments. Therefore, it is rational to expect that newly acceding countries were asked to commit at the globally efficient tariff level in exchange for the right of membership.

Table 8 reports the results of our IV estimations. For comparison, the table also reports results of OLS estimates on the same sub-sample of countries. Column 1 shows that the bound rate has a significant and negative effect on the probability of a tariff increase, even controlling for endogeneity. Furthermore, the results of first stage estimations support the hypothesis that the instruments are valid and the coefficients on the instruments are consistent with the theoretical predictions. The bound rate

\footnotetext{
${ }^{23}$ After dropping observations with missing values in any of the variables included in our specification, our instrumental variable regression sample includes the following twelve countries: Albania, Armenia, Cambodia, Cape Verde, China, Former Yugoslav Republic of Macedonia, Georgia, Lithuania, Nepal, Saudi Arabia, Ukraine, Viet Nam.
} 
is positively correlated with the pre-accession applied tariff and negatively correlated with average pre-accession import volumes over world prices. As regards the magnitude of the coefficients, the comparison between the OLS and IV estimated coefficients for the bound rate shows that OLS estimates are downward biased. This suggests that our baseline results represent a lower bound of the actual effect of WTO commitments.

IV results for water and effective water (columns 2, 3) also support the view that our findings are robust to endogeneity. Note that the sign of the coefficients of the first stage estimates are opposite to those obtained when instrumenting the bound rate. This is because the water is also determined by the MFN applied rate, and the water can be low when the bound and the MFN applied rate are high. 
Table 8: Robustness to endogeneity (sub-sample of countries that joined the WTO since 2000)

\begin{tabular}{|c|c|c|c|c|c|c|}
\hline & \multicolumn{6}{|c|}{ Dependent variable: $1=$ MFN applied tariff increase } \\
\hline & \multicolumn{3}{|c|}{ 2SLS } & \multicolumn{3}{|c|}{ OLS } \\
\hline & (1) & (2) & (3) & (4) & (5) & (6) \\
\hline \multicolumn{7}{|l|}{ WTO flexibility } \\
\hline $\operatorname{Ln}(1+\text { Bound rate })_{\mathrm{ckt}}$ & $\begin{array}{l}0.279 * * \\
{[0.116]}\end{array}$ & & & $\begin{array}{c}0.160 * * * \\
{[0.012]}\end{array}$ & & \\
\hline $\operatorname{Ln}(1+\text { Prohibitive tariff })_{\mathrm{ckt}}$ & $\begin{array}{c}0.003^{* * *} \\
{[0.001]}\end{array}$ & & & $\begin{array}{c}0.003^{* * *} \\
{[0.001]}\end{array}$ & & \\
\hline $\operatorname{Ln}(1+\text { MFN applied tariff })_{\text {ckt }-1}$ & $\begin{array}{c}-0.237 * * * \\
{[0.079]}\end{array}$ & & & $\begin{array}{c}-0.157 * * * \\
{[0.011]}\end{array}$ & & \\
\hline Water $_{\text {ckt }}$ & & $\begin{array}{c}0.101^{* * *} \\
{[0.026]}\end{array}$ & & & $\begin{array}{c}0.132 * * * \\
{[0.009]}\end{array}$ & \\
\hline${\text { Effective } \text { water }_{\text {ckt }}}$ & & & $\begin{array}{c}0.106^{* * *} \\
{[0.026]}\end{array}$ & & & $\begin{array}{c}0.137^{* * *} \\
{[0.010]}\end{array}$ \\
\hline \multicolumn{7}{|l|}{ Bagwell and Staiger's model } \\
\hline$\Delta$ (Share of imports) $)_{\text {ckt-1 }}$ & $\begin{array}{c}0.009 \\
{[0.010]}\end{array}$ & $\begin{array}{c}0.008 \\
{[0.010]}\end{array}$ & $\begin{array}{c}0.009 \\
{[0.010]}\end{array}$ & $\begin{array}{c}0.008 \\
{[0.010]}\end{array}$ & $\begin{array}{c}0.008 \\
{[0.010]}\end{array}$ & $\begin{array}{c}0.009 \\
{[0.010]}\end{array}$ \\
\hline Std. Dev. of $\Delta$ (Share of imports $)_{\mathrm{ck}}$ & $\begin{array}{c}-0.064^{* * *} \\
{[0.014]}\end{array}$ & $\begin{array}{c}-0.064^{* * *} \\
{[0.014]}\end{array}$ & $\begin{array}{c}-0.066^{* * *} \\
{[0.014]}\end{array}$ & $\begin{array}{c}-0.065^{* * *} \\
{[0.014]}\end{array}$ & $\begin{array}{c}-0.064^{* * *} \\
{[0.014]}\end{array}$ & $\begin{array}{c}-0.066 * * * \\
{[0.014]}\end{array}$ \\
\hline Share of imports ${ }_{\mathrm{ck}}$ & $\begin{array}{c}0.051^{* * *} \\
{[0.008]}\end{array}$ & $\begin{array}{c}0.048 * * * \\
{[0.008]}\end{array}$ & $\begin{array}{c}0.050^{* * *} \\
{[0.008]}\end{array}$ & $\begin{array}{c}0.050 * * * \\
{[0.008]}\end{array}$ & $\begin{array}{c}0.048 * * * \\
{[0.008]}\end{array}$ & $\begin{array}{c}0.050^{* * *} \\
{[0.008]}\end{array}$ \\
\hline \multicolumn{7}{|l|}{ Economic and institutional variables } \\
\hline $\ln (\mathrm{GDP})_{\mathrm{ct}-1}$ & $\begin{array}{c}0.007 \\
{[0.005]}\end{array}$ & $\begin{array}{l}0.008^{*} \\
{[0.005]}\end{array}$ & $\begin{array}{l}0.008^{*} \\
{[0.005]}\end{array}$ & $\begin{array}{c}0.008 \\
{[0.005]}\end{array}$ & $\begin{array}{c}0.008 \\
{[0.005]}\end{array}$ & $\begin{array}{c}0.008 \\
{[0.005]}\end{array}$ \\
\hline GDP growth $\mathrm{ct}_{\mathrm{ct}-1}$ & $\begin{array}{c}-0.000 \\
{[0.007]}\end{array}$ & $\begin{array}{c}-0.003 \\
{[0.006]}\end{array}$ & $\begin{array}{c}-0.003 \\
{[0.007]}\end{array}$ & $\begin{array}{c}-0.002 \\
{[0.007]}\end{array}$ & $\begin{array}{c}-0.003 \\
{[0.006]}\end{array}$ & $\begin{array}{c}-0.003 \\
{[0.007]}\end{array}$ \\
\hline Average PTA depth $\mathrm{ct}_{\mathrm{t}}$ & $\begin{array}{c}0.001^{* * *} \\
{[0.000]}\end{array}$ & $\begin{array}{c}0.001 * * * \\
{[0.000]}\end{array}$ & $\begin{array}{c}0.001^{* * *} \\
{[0.000]}\end{array}$ & $\begin{array}{c}0.001 * * * \\
{[0.000]}\end{array}$ & $\begin{array}{c}0.001^{* * *} \\
{[0.000]}\end{array}$ & $\begin{array}{c}0.001^{* * *} \\
{[0.000]}\end{array}$ \\
\hline$(\text { Custom Union)*(Average PTA depth) })_{\mathrm{ct}}$ & $\begin{array}{c}0.013 \\
{[0.010]}\end{array}$ & $\begin{array}{l}0.017^{*} \\
{[0.009]}\end{array}$ & $\begin{array}{l}0.017^{*} \\
{[0.010]}\end{array}$ & $\begin{array}{l}-0.000 \\
{[0.001]}\end{array}$ & $\begin{array}{l}-0.000 \\
{[0.001]}\end{array}$ & $\begin{array}{c}-0.000 \\
{[0.001]}\end{array}$ \\
\hline Custom Union & $\begin{array}{l}-0.117^{*} \\
{[0.070]}\end{array}$ & $\begin{array}{c}-0.137^{* *} \\
{[0.065]}\end{array}$ & $\begin{array}{c}-0.137^{* *} \\
{[0.066]}\end{array}$ & & & \\
\hline Trade Policy Review $\mathrm{ct}-1_{1}$ & $\begin{array}{l}-0.003 \\
{[0.002]}\end{array}$ & $\begin{array}{c}-0.003^{*} \\
{[0.002]}\end{array}$ & $\begin{array}{c}-0.003 \\
{[0.002]}\end{array}$ & $\begin{array}{c}-0.003 \\
{[0.002]}\end{array}$ & $\begin{array}{c}-0.003 * \\
{[0.002]}\end{array}$ & $\begin{array}{c}-0.003 \\
{[0.002]}\end{array}$ \\
\hline \multicolumn{7}{|l|}{ First stage } \\
\hline Pre-accession (Import quantity/p) $)_{c k}$ & $\begin{array}{c}-0.000 * * \\
{[0.000]}\end{array}$ & $\begin{array}{c}-0.000 * * * \\
{[0.000]}\end{array}$ & $\begin{array}{c}-0.000^{* * *} \\
{[0.000]}\end{array}$ & & & \\
\hline Ln(1+Pre-accession MFN applied tariff $\left.{ }_{\mathrm{ck}}\right)$ & $\begin{array}{c}0.075^{* * *} \\
{[0.008]}\end{array}$ & $\begin{array}{c}-0.204^{* * *} \\
{[0.008]}\end{array}$ & $\begin{array}{c}-0.206^{* * *} \\
{[0.008]}\end{array}$ & & & \\
\hline Observations & 342,057 & 349,832 & 342,057 & 342,057 & 349,832 & 342,057 \\
\hline F-test of excluded instruments & 41.72 & 342.1 & 347.1 & & & \\
\hline Hansen p-value & 0.255 & 0.398 & 0.442 & & & \\
\hline
\end{tabular}

Note: All regressions include country, year and industry (2 digit) fixed effects. ***, **, *, ${ }^{*}$ indicate significance at 1, 5, 10, and 15 percent level. Robust standard errors in parentheses, clustered by country-industry (4 digit). 


\subsection{Controlling for political economy factors}

As a final robustness test, we include in our model the traditional political economy variables that have been shown to affect tariff changes, such as employment and the value added (VA) to output ratio. The traditional argument is that the probability of a tariff increase augments with the number of employees in the industry, because the lobby power exercised by a sector is higher the larger the sector. In contrast, the probability of a tariff increase should decrease with the value added to output ratio, because a low value added over output ratio typically characterises upstream industries producing simple homogeneous goods. These are sectors more likely to ask for protection because they are more sensitive to price changes.

In order to perform this robustness test, we aggregated the database to 4-digit because UNIDO data on employment, output and VA are available only at the 4-digit ISIC Rev. 3. The dependent variable $y$ of equation (1), in the case of 4 digit regression, is the number of tariff increases at the six-digit level that fall in the same 4-digit sector. Therefore, we estimate the 4-digit equation using a poisson model. All industrial covariates are lagged to avoid endogeneity. Sectoral fixed effects are at the 2-digit level.

In Table 9, we first show that B\&S variables for TPU and WTO flexibility also work for the aggregated 4-digit model (column 1). All coefficients have the expected signs. When we control for political economy variables, while the variables measuring flexibility under the WTO remain statistically significant and with the expected signs, our measure of an unexpected import surge loses statistical significance. The level of employment shows the expected positive coefficient and it is found to be a significant determinant of TPU. The value added to output ratio is not significant, but it has the correct sign. These results somewhat weaken the role of TOT-arguments in explaining tradepolicy variability. However, even when protectionist pressures are justified by factors other than an unexpected import surge (such as lobby pressures), some of the main predictions of the model continue to hold. 


\begin{tabular}{|c|c|c|c|c|}
\hline & \multicolumn{4}{|c|}{ Dependent variable $=$ number of 6 digit tariff increases } \\
\hline & $(1)$ & $(2)$ & (3) & $(4)$ \\
\hline \multicolumn{5}{|l|}{ WTO flexibility } \\
\hline $\operatorname{Ln}(1+\text { Bound rate })_{\mathrm{ckt}}$ & $\begin{array}{c}2.245^{* * *} \\
{[0.264]}\end{array}$ & $\begin{array}{c}1.736 * * * \\
{[0.617]}\end{array}$ & & \\
\hline $\operatorname{Ln}(1+\text { Prohibitive tariff })_{\mathrm{ckt}}$ & $\begin{array}{c}0.814 * * * \\
{[0.147]}\end{array}$ & $\begin{array}{c}1.421^{* * *} \\
{[0.248]}\end{array}$ & & \\
\hline Ln(1 + MFN applied tariff $)_{\text {ckt-1 }}$ & $\begin{array}{c}-4.624 * * * \\
{[0.642]}\end{array}$ & $\begin{array}{c}-3.908 * * * \\
{[0.886]}\end{array}$ & & \\
\hline Water $_{\text {ckt }}$ & & & $\begin{array}{c}1.065^{* * *} \\
{[0.304]}\end{array}$ & \\
\hline Effective water $_{\text {ckt }}$ & & & & $\begin{array}{c}1.583^{* * *} \\
{[0.296]}\end{array}$ \\
\hline \multicolumn{5}{|l|}{ Political economy } \\
\hline Ln (N. employees) $)_{\text {ckt-1 }}$ & & $\begin{array}{c}0.068 * * * \\
{[0.022]}\end{array}$ & $\begin{array}{c}0.073 * * * \\
{[0.021]}\end{array}$ & $\begin{array}{c}0.074 * * * \\
{[0.022]}\end{array}$ \\
\hline (Value added / output $)_{\text {ckt-1 }}$ & & $\begin{array}{l}-0.030 \\
{[0.171]}\end{array}$ & $\begin{array}{c}-0.017 \\
{[0.168]}\end{array}$ & $\begin{array}{c}-0.004 \\
{[0.171]}\end{array}$ \\
\hline \multicolumn{5}{|l|}{ Bagwell and Staiger's model } \\
\hline$\Delta(\text { Share of imports })_{\mathrm{ckt}-1}$ & $\begin{array}{c}15.530 * * * \\
{[5.079]}\end{array}$ & $\begin{array}{c}0.675 \\
{[6.801]}\end{array}$ & $\begin{array}{l}-0.030 \\
{[6.554]}\end{array}$ & $\begin{array}{c}0.259 \\
{[6.772]}\end{array}$ \\
\hline Std. Dev. of $\Delta$ (Share of imports $)_{\mathrm{ck}}$ & $\begin{array}{c}-25.699 * * * \\
{[7.691]}\end{array}$ & $\begin{array}{c}-13.350^{*} \\
{[7.640]}\end{array}$ & $\begin{array}{c}-16.158^{* *} \\
{[7.360]}\end{array}$ & $\begin{array}{c}-18.059^{* *} \\
{[7.232]}\end{array}$ \\
\hline Share of imports $\mathrm{ck}_{\mathrm{k}}$ & $\begin{array}{l}2.640^{*} \\
{[1.462]}\end{array}$ & $\begin{array}{c}1.569 \\
{[1.821]}\end{array}$ & $\begin{array}{l}3.976 * * \\
{[1.670]}\end{array}$ & $\begin{array}{l}3.715^{* *} \\
{[1.672]}\end{array}$ \\
\hline \multicolumn{5}{|l|}{ Economic and institutional variables } \\
\hline $\ln (\mathrm{GDP})_{\mathrm{ct}-1}$ & $\begin{array}{c}-0.677 * * * \\
{[0.190]}\end{array}$ & $\begin{array}{l}-0.030 \\
{[0.369]}\end{array}$ & $\begin{array}{l}-0.027 \\
{[0.380]}\end{array}$ & $\begin{array}{l}-0.025 \\
{[0.377]}\end{array}$ \\
\hline GDP growth $_{\mathrm{ct}-1}$ & $\begin{array}{c}-1.190 * * * \\
{[0.354]}\end{array}$ & $\begin{array}{c}-1.794 * * * \\
{[0.527]}\end{array}$ & $\begin{array}{c}-1.867 * * * \\
{[0.564]}\end{array}$ & $\begin{array}{c}-1.865^{* * *} \\
{[0.556]}\end{array}$ \\
\hline Average PTA depth ${ }_{\mathrm{ct}}$ & $\begin{array}{c}0.125^{* * *} \\
{[0.019]}\end{array}$ & $\begin{array}{c}0.136 * * * \\
{[0.026]}\end{array}$ & $\begin{array}{c}0.139 * * * \\
{[0.026]}\end{array}$ & $\begin{array}{c}0.138^{* * *} \\
{[0.026]}\end{array}$ \\
\hline (Custom Union)*(Average PTA depth) ${ }_{\mathrm{ct}}$ & $\begin{array}{c}0.001 \\
{[0.047]}\end{array}$ & $\begin{array}{c}0.058 \\
{[0.073]}\end{array}$ & $\begin{array}{c}0.058 \\
{[0.072]}\end{array}$ & $\begin{array}{c}0.060 \\
{[0.071]}\end{array}$ \\
\hline Custom Union & $\begin{array}{c}-2.007 * * * \\
{[0.506]}\end{array}$ & $\begin{array}{c}-3.575 * * * \\
{[0.593]}\end{array}$ & $\begin{array}{c}-3.617^{* * *} \\
{[0.590]}\end{array}$ & $\begin{array}{c}-3.630^{* * *} \\
{[0.588]}\end{array}$ \\
\hline Trade Policy Review $_{\mathrm{ct}-1}$ & $\begin{array}{l}-0.178^{*} \\
{[0.098]}\end{array}$ & $\begin{array}{c}-0.515^{* * *} \\
{[0.167]}\end{array}$ & $\begin{array}{c}-0.515^{* * *} \\
{[0.168]}\end{array}$ & $\begin{array}{c}-0.515^{* * *} \\
{[0.168]}\end{array}$ \\
\hline N. of sectoral tariff lines & $\begin{array}{c}0.007 * * * \\
{[0.000]}\end{array}$ & $\begin{array}{c}0.006 * * * \\
{[0.000]}\end{array}$ & $\begin{array}{c}0.006 * * * \\
{[0.000]}\end{array}$ & $\begin{array}{c}0.006^{* * *} \\
{[0.000]}\end{array}$ \\
\hline $\begin{array}{l}\text { Observations } \\
\text { Log-Likelihood }\end{array}$ & $\begin{array}{l}108,369 \\
-228822\end{array}$ & $\begin{array}{l}25,334 \\
-57049\end{array}$ & $\begin{array}{l}25,475 \\
-58182\end{array}$ & $\begin{array}{l}25,334 \\
-57653\end{array}$ \\
\hline
\end{tabular}

Note: All regressions include country, year, and industry fixed effects. An industry is defined at the ISIC 2-digit level. **, **, * indicate significance at 1,5,10 percent level. Robust standard errors in parentheses, clustered by country-industry (2 digit). The sample only includes bound lines. 


\section{Conclusions}

The central question of this paper is whether WTO binding rates set above MFN applied tariffs have an effect on trade policy uncertainty. It is widely recognised among policymakers that one of the aims of trade agreements, and of the WTO in particular, is to ensure the stability and predictability of trade conditions. Models of trade agreements show that risk-averse governments may have an uncertaintyreducing motive for trade agreements or that a binding overhang exists to strike a balance between flexibility and rigidity of commitments under asymmetric shocks and private information about the shocks. Nevertheless, empirical evidence that trade agreements in general, and WTO in particular, reduce trade policy uncertainty is scant and it is in general not based on a theoretically grounded empirical model.

Relying on the B\&S model of time-varying cooperative tariffs, we study the determinants of trade policy uncertainty, focusing on the role of WTO commitments.

To this purpose, we build a new database of WTO binding rates for the Organization's Member countries, from 1996 through 2011, at disaggregated sectoral level. Previously available databases only record the final bound rate. However, often countries commit to gradually reduce their bound rate from an initial base rate to a final bound rate over a certain period of time. Therefore, the bound rate in force varies over time, depending on the negotiated implementation period. The main novelty of our database is that it accounts for the changes in the bound rate in force at each moment in time.

Our results suggest that there are significant potential gains from signing a trade agreement in addition to that of reducing tariff rates.

We also show how a model of trade policy uncertainty can be used to shed light on other important questions such as the relationship between preferential trade agreements and the WTO, the use of tariff increases as a way to respond to an economic downturns (the extent of protectionist reactions to a crisis), and the benefits of other WTO activities such as monitoring and surveillance. Our results suggest that trade policy is counter-cyclical, that preferential and multilateral liberalization are substitutes and monitoring brings about benefits in terms of trade policy stability. 


\section{Bibliography}

Bagwell, K. and Staiger, R. W. (1990). A Theory of Managed Trade. American Economic Review, 80(4), 779-795.

Bagwell, K. and Staiger, R. W. (1999a). An Economic Theory of GATT. American Economic Review, 89(1), 215-248.

Bagwell, K. and Staiger, R. W. (1999b). Regionalism and Multilateral Tariff Cooperation. International Trade Policy and the Pacific Rim (St. Martin.). New York, NY.

Bagwell, K. and Staiger, R. W. (2003). Protection and the Business Cycle. Advances in Economic Analysis \& Policy, 3(1), 1-43.

Bagwell, K. and Staiger, R. W. (2011). What Do Trade Negotiators Negotiate About? Empirical Evidence from the World Trade Organization, American Economic Review, 101(4), 1238-1273.

Beshkar, M., Bond, E., and Rho, Y. (2012). Tariff Binding and Overhang: Theory and Evidence. mimeo, available at http://ssrn.com/abstract $=2007095$

Bohara, A. K. and Kaempfer, W. H. (1991). A Test of Tariff Endogeneity in the United States. American Economic Review, 81(4), 952-960.

Bond, E. W., Raymond, G. R., and Syropoulos, C. (2004). A strategic and welfare theoretic analysis of free trade areas. Journal of International Economics, 64(1), 1-27.

Bond, E. W. and Syropoulos, C. (1996). The Size of Trading Blocs: Market Power and World Welfare Effects. Journal of International Economics, 40(3-4), 11-37.

Bown, C. P., and Crowley, M. A. (2013). Self-Enforcing Trade Agreements: Evidence from TimeVarying Trade Policy. American Economic Review, 103(2), 1071-1090.

Broda, C., Greenfield, J., and Weinstein, D. (2006). From Groundnuts to Globalization: A Structural Estimate of Trade and Growth. NBER Working Paper 12512.

Broda, C., Limão, N., and Weinstein, D. E. (2008). Optimal Tariffs and Market Power: The Evidence. American Economic Review, 98(5), 2032-2065.

Cadot, O., Olarreaga, M., and Tschopp, J. (2010). Do Trade Agreements Reduce the Volatility of Agricultural Assistance Rates? The Political Economy of Agricultural Trade Distorsions. Cambridge University Press.

Cassing, J., McKeown, T. J., and Ochs, J. (1986). The Political Economy of the Tariff Cycle. American Political Science Review, 80(3), 843-862.

Crowley, M.A. (2011). Cyclical dumping and US antidumping protection: 1980-2001. Federal Reserve Bank of Chicago Working Paper (WP-2007-21).

Estevadeordal, A., Freund, C., and Ornelas, E. (2008). Does Regionalism Affect Trade Liberalization Towards Nonmembers? Quarterly Journal of Economics, 123(4), 1531-1575. 
Finger, J.M., Hall H.K., and Nelson, D.R. (1982), The Political Economy of Administrated Protection. American Economic Review, 72(3), 452-466.

Foletti, L., Fugazza, M., Nicita, A., and Olarreaga, M. (2011). Smoke in the (Tariff) Water. The World Economy, 34(2), 248-264.

Freund, C. (2000). Multilateralism and the endogenous formation of preferential trade agreements. Journal of International Economics, 52(2), 359-376.

Freund, C. and Pierola, M.D. (2010a). Export Entrepreneurs. Evidence from Peru, Policy Research Working Paper 5407. The World Bank.

Freund, C. and Pierola, M.D. (2010b). Global Patterns in Exporter Entry and Exit. mimeo.

Fugazza, M. and Nicita, A. (2011). Measuring preferential market access. MPRA Paper 38565, University Library of Munich, Germany.

Grilli, E. (1988). Macro-economic Determinants of Trade Protection. The World Economy, 11(3), 313-326.

Handley, K. (2014). Exporting Under Trade Policy Uncertainty: Theory and Evidence. Journal of Interantional Economics, 94(1), 50-66.

Handley, K. and Limão, N. (2012). Trade and Investment under Policy Uncertainty: Theory and Firm Evidence. NBER Working Paper 17790, forthcoming AEJ Policy.

Handley, K. and Limão, N. (2014). Policy Uncertainty, Trade and Welfare: Theory and Evidence for China and the U.S. NBER Working Paper 19376.

Horn, H., Maggi, G., and Staiger R.W. (2010) Trade Agreement as Endogenously Incomplete Contracts American Economic Review, 100(1), 394-419.

Kee, H. L., Nicita, A., and Olarreaga, M. (2008). Import Demand Elasticities and Trade Distorsions. Review of Economics and Statistics, 90(4), 666-682.

King, G. and Zeng, L. (2001). Logistic Regression in Rare Events Data. Political Analysis, 9, 137163.

Knetter, M. M. and Prusa, T. J. (2003). Macroeconomic factors and antidumping filings: evidence from four countries. Journal of International Economics, 61(1), 1-17.

Limão, N. (2007). Are Preferential Trade Agreements with Non-trade Objectives a Stumbling Block for Multilateral Liberalization? Review of Economic Studies, 74(3), 821-855.

Limão, N. and Maggi, G. (2013). Uncertainty and Trade Agreements. NBER Working Paper 18703, forthcoming AEJ Micro.

Ludema, R.D. and Mayda, A. M. (2013). Do terms-of-trade effects matter for trade agreements? Theory and Evidence from WTO Countries. Quarterly Journal of Economics, 128(4), 18371893. 
Maggi, G. and Rodriguez-Clare, A. (1998). The Value of Trade Agreements in the Presence of Political Pressures. Journal of Political Economy, 106(3), 574-601.

Mansfield, E. D. and Reinhardt, E. (2008). International Institutions and the Volatility of International Trade. International Organization, 62(4), 621-652.

Ornelas, E. (2007). Exchanging Market Access at the Outsiders' Expense: The Case of Customs Unions. Canadian Journal of Economics, 40(1), 207-224.

Rose, A. K. (2004). Do WTO members have more liberal trade policy? Journal of International Economics, 63(2), 209-235.

Rose, A. K. (2005). Does the WTO Make Trade More Stable? Open Economies Review, 16, 7-22.

Rose, A.K. ( 2013). The march of an economic idea? Protectionism isn't counter-cyclic (anymore). Economic Policy, October, 569-612.

Sala, D., Schröder, P. J. H. and Yalcin, E. (2010). Market Access Through Bound Tariffs. Scottish Journal of Political Economy, 57(3), 272-289.

Wold Trade Organization (WTO), (2009). World Trade Report 2009. Trade Policy Commitments and Contingency Measures, Geneva.

World Trade Organization (WTO), (2014). Report on G-20 Trade Measures, 5 November 2014. available at http://www.wto.org/english/news_e/news14_e/g20_wto_report_oct14_e.pdf 


\section{Appendix A: Data sources}

We discuss in the main text how we construct the database on the bound rate, using thw WTO CTS database and other WTO documents on practices and schedules of commitments.

Data on MFN applied rates are from the WTO's Integrated Data Base (IDB) and UNCTAD's Trade Analysis and Information System (TRAINS). We used TRAINS as primary source and IDB to fill the gaps. ${ }^{24}$ Only ad valorem tariffs are used in the analysis, with data covering the 1996-2011 period. ${ }^{25}$ Original data are collected in different 6-digit HS classifications (HS 1992, 1996, 2002, 2007), depending on the year and the country. We converted tariff data to the HS 1996 nomenclature, using concordance tables. ${ }^{26}$ To calculate the prohibitive tariff we used import demand elasticities from Kee, Nicita and Olarreaga (2008).

Import data are from UN COMTRADE, available at the HS 1996, except for the European Union whose import data are from Eurostat. We converted Eurostat data to HS 1996. GDP data are from the World Bank Development Indicators.

In order to obtain PTA depth, we rely on a newly built database by the WTO Secretariat. This database maps the provisions covered in 96 PTAs. These include both provisions already covered in the WTO agreements, but that proceed further in liberalizing trade (the so called WTO-plus provision) and provisions related to issues that are not addressed in the WTO agreement (WTO-X provision) (See WTO, World Trade Report 2011). First we construct the depth of a PTA as the number of provisions covered in the agreement. Then, we obtain the average depth of the PTAs by country-year.

Data on employment, output and value added are from UNIDO INDSTAT 2012, at the 4-digit ISIC Rev. 3 level of sectoral disaggregation. All data are converted to 4-digit ISIC Rev. 3 for the analysis including political economy determinants of tariffs (table 9).

\footnotetext{
${ }^{24}$ The distribution of the tariff variable which uses IDB as primary source is almost identical.

${ }^{25}$ The European Union (EU) is included in the dataset as a single aggregate. Data on the EU refer to EU-15 from 1996 to 2004, to EU-25 from 2004 to 2006, and to EU-27 from 2007 onwards. For those countries that acceded the EU in 2004 (Cyprus, Czech Republic, Estonia, Hungary, Latvia, Lithuania, Malta, Poland, Slovakia and Slovenia) or 2007 (Bulgaria and Romania), data cover the period from 1996 to the year before EU accession.

${ }^{26}$ We used the conversion tables prepared by the UN Statistics Division, available online at http://unstats.un.org/unsd/trade/conversions/HS\%20Correlation\%20and\%20Conversion\%20tables.htm (last access: December 2014).
} 
Appendix B: Detailed sample composition of descriptive Tables 1 and 2

Table B.1. Number of observations of the sample in Table 1

\begin{tabular}{|c|c|c|c|c|c|c|c|}
\hline & \multicolumn{3}{|c|}{ Beginning of period } & \multicolumn{3}{|c|}{ End of period } & \multirow[b]{2}{*}{ Total } \\
\hline & 1996 & 1997 & 1998 & 2009 & 2010 & 2011 & \\
\hline Albania & 5,113 & 5,113 & 5,113 & 5,113 & 5,113 & 5,113 & 30,678 \\
\hline Algeria & 0 & 4,745 & 4,745 & 4,745 & 4,745 & 0 & 18,980 \\
\hline Argentina & 5,094 & 5,094 & 5,094 & 5,094 & 5,094 & 5,094 & 30,564 \\
\hline Armenia & 0 & 5,113 & 0 & 5,113 & 5,113 & 5,113 & 20,452 \\
\hline Australia & 4,992 & 5,100 & 5,100 & 5,100 & 5,100 & 5,100 & 30,492 \\
\hline Belize & 0 & 0 & 5,113 & 5,113 & 5,113 & 5,113 & 20,452 \\
\hline Benin & 0 & 0 & 5,113 & 5,113 & 5,113 & 0 & 15,339 \\
\hline Bolivarian Rep. of Venezuela & 5,113 & 5,113 & 5,113 & 5,113 & 5,113 & 5,113 & 30,678 \\
\hline Bolivia & 0 & 5,113 & 5,113 & 5,113 & 5,113 & 5,113 & 25,565 \\
\hline Brazil & 0 & 5,113 & 5,113 & 5,113 & 5,113 & 5,113 & 25,565 \\
\hline Canada & 5,044 & 5,044 & 5,044 & 5,044 & 5,044 & 5,044 & 30,264 \\
\hline Cape Verde & 0 & 5,113 & 5,113 & 5,113 & 5,113 & 5,113 & 25,565 \\
\hline Central African Rep. & 0 & 5,113 & 5,113 & 5,113 & 5,113 & 5,113 & 25,565 \\
\hline Chile & 0 & 5,113 & 5,113 & 5,113 & 5,113 & 5,113 & 25,565 \\
\hline China & 5,113 & 5,113 & 5,113 & 5,113 & 5,113 & 5,113 & 30,678 \\
\hline Colombia & 5,113 & 5,113 & 5,113 & 5,113 & 5,113 & 5,113 & 30,678 \\
\hline Costa Rica & 0 & 5,113 & 5,113 & 5,113 & 5,113 & 5,113 & 25,565 \\
\hline Croatia & 0 & 5,047 & 5,047 & 5,047 & 5,047 & 5,047 & 25,235 \\
\hline Ecuador & 5,113 & 5,113 & 5,113 & 5,113 & 5,113 & 5,113 & 30,678 \\
\hline El Salvador & 0 & 5,113 & 5,113 & 5,113 & 5,113 & 5,113 & 25,565 \\
\hline European Communities & 4,514 & 4,518 & 4,520 & 4,518 & 4,523 & 4,521 & 27,114 \\
\hline Former Yugoslav Rep. of Macedonia & 5,062 & 5,062 & 5,062 & 5,062 & 5,062 & 5,062 & 30,372 \\
\hline Gabon & 0 & 5,113 & 5,113 & 5,113 & 0 & 0 & 15,339 \\
\hline Gambia & 5,113 & 5,113 & 5,113 & 5,113 & 5,113 & 5,113 & 30,678 \\
\hline Georgia & 0 & 0 & 5,096 & 5,096 & 5,096 & 5,096 & 20,384 \\
\hline Guatemala & 0 & 5,079 & 5,079 & 5,079 & 5,079 & 5,079 & 25,395 \\
\hline Guyana & 0 & 5,113 & 5,113 & 5,113 & 5,113 & 5,113 & 25,565 \\
\hline Honduras & 0 & 5,113 & 5,113 & 5,113 & 0 & 0 & 15,339 \\
\hline Hong Kong, China & 4,654 & 4,801 & 4,801 & 4,801 & 4,801 & 4,801 & 28,659 \\
\hline Iceland & 0 & 4,965 & 4,965 & 4,965 & 4,965 & 4,965 & 24,825 \\
\hline India & 4,841 & 4,841 & 4,841 & 4,841 & 4,841 & 4,841 & 29,046 \\
\hline Indonesia & 5,113 & 5,113 & 5,113 & 5,113 & 5,113 & 5,113 & 30,678 \\
\hline Israel & 4,879 & 4,879 & 4,879 & 4,879 & 4,879 & 4,879 & 29,274 \\
\hline Jamaica & 0 & 0 & 5,111 & 5,111 & 5,111 & 0 & 15,333 \\
\hline Japan & 5,037 & 5,040 & 5,040 & 5,040 & 5,040 & 5,040 & 30,237 \\
\hline Jordan & 0 & 0 & 5,108 & 5,108 & 5,108 & 5,108 & 20,432 \\
\hline Kenya & 0 & 5,113 & 5,113 & 5,113 & 5,113 & 0 & 20,452 \\
\hline Korea, Republic of & 5,095 & 5,095 & 5,095 & 5,095 & 5,095 & 5,095 & 30,570 \\
\hline Macao, China & 4,911 & 5,113 & 5,113 & 5,113 & 5,113 & 0 & 25,363 \\
\hline Madagascar & 5,113 & 5,113 & 5,113 & 5,113 & 5,113 & 5,113 & 30,678 \\
\hline Malaysia & 0 & 5,001 & 5,001 & 5,001 & 5,001 & 5,001 & 25,005 \\
\hline Maldives & 0 & 5,113 & 5,113 & 5,113 & 5,113 & 5,113 & 25,565 \\
\hline Mali & 0 & 0 & 5,113 & 0 & 5,113 & 0 & 10,226 \\
\hline Mauritius & 0 & 5,113 & 5,113 & 5,113 & 5,113 & 5,113 & 25,565 \\
\hline Mexico & 5,073 & 5,073 & 5,073 & 5,073 & 5,073 & 5,073 & 30,438 \\
\hline
\end{tabular}


Table B.1. Number of observations of the sample in Table 1 (continued)

\begin{tabular}{|c|c|c|c|c|c|c|c|}
\hline & \multicolumn{3}{|c|}{ Beginning of period } & \multicolumn{3}{|c|}{ End of period } & \multirow[b]{2}{*}{ Total } \\
\hline & 1996 & 1997 & 1998 & 2009 & 2010 & 2011 & \\
\hline Nepal & 0 & 0 & 5,113 & 5,113 & 5,113 & 5,113 & 20,452 \\
\hline New Zealand & 5,099 & 5,099 & 5,099 & 5,099 & 5,099 & 5,099 & 30,594 \\
\hline Nicaragua & 0 & 5,113 & 5,113 & 5,113 & 5,113 & 5,113 & 25,565 \\
\hline Niger & 0 & 0 & 5,113 & 5,113 & 5,113 & 5,113 & 20,452 \\
\hline Norway & 4,658 & 4,658 & 4,658 & 4,658 & 4,658 & 4,658 & 27,948 \\
\hline Panama & 0 & 0 & 5,113 & 5,113 & 5,113 & 5,113 & 20,452 \\
\hline Paraguay & 0 & 0 & 5,113 & 5,113 & 5,113 & 5,113 & 20,452 \\
\hline Peru & 0 & 0 & 5,113 & 5,113 & 5,113 & 5,113 & 20,452 \\
\hline Russian Federation & 0 & 4,745 & 0 & 4,745 & 4,745 & 4,745 & 18,980 \\
\hline Saint Vincent and the Grenadines & 0 & 0 & 5,113 & 5,113 & 5,113 & 5,113 & 20,452 \\
\hline Senegal & 5,113 & 5,113 & 5,113 & 5,113 & 5,113 & 5,113 & 30,678 \\
\hline Singapore & 0 & 5,090 & 5,090 & 5,090 & 5,090 & 5,090 & 25,450 \\
\hline Switzerland & 938 & 1,114 & 1,114 & 1,114 & 1,114 & 1,114 & 6,508 \\
\hline Tanzania & 0 & 5,113 & 5,113 & 5,113 & 5,113 & 5,113 & 25,565 \\
\hline Togo & 0 & 0 & 5,113 & 5,113 & 5,113 & 5,113 & 20,452 \\
\hline Turkey & 5,110 & 5,110 & 5,110 & 5,110 & 5,110 & 5,110 & 30,660 \\
\hline Uganda & 5,113 & 5,113 & 5,113 & 5,113 & 5,113 & 5,113 & 30,678 \\
\hline United States & 4,798 & 4,798 & 4,798 & 4,798 & 4,798 & 4,798 & 28,788 \\
\hline Uruguay & 0 & 5,113 & 5,113 & 5,113 & 0 & 0 & 15,339 \\
\hline Zambia & 0 & 5,113 & 5,113 & 5,113 & 5,113 & 5,113 & 25,565 \\
\hline
\end{tabular}

Table B.2. Number of observations of the sample in Table 2

\begin{tabular}{|c|c|c|c|c|c|c|c|}
\hline & \multicolumn{3}{|c|}{ Beginning of period } & \multicolumn{3}{|c|}{ End of period } & \multirow[b]{2}{*}{ Total } \\
\hline & 1996 & 1997 & 1998 & 2009 & 2010 & 2011 & \\
\hline Albania & 0 & 4,745 & 0 & 4,745 & 4,745 & 4,745 & 18,980 \\
\hline Algeria & 0 & 4,745 & 4,745 & 4,745 & 4,745 & 0 & 18,980 \\
\hline Argentina & 4,726 & 4,726 & 4,726 & 4,726 & 4,726 & 4,190 & 27,820 \\
\hline Australia & 4,644 & 4,730 & 4,731 & 4,731 & 4,730 & 4,730 & 28,296 \\
\hline Bolivarian Rep. of & & & & & & & \\
\hline Venezuela & 0 & 5,035 & 5,035 & 5,035 & 5,035 & 5,035 & 25,175 \\
\hline Bolivia & 0 & 4,745 & 4,745 & 4,745 & 4,745 & 4,745 & 23,725 \\
\hline Brazil & 0 & 4,745 & 4,745 & 4,745 & 4,745 & 4,745 & 23,725 \\
\hline Canada & 4,651 & 4,643 & 4,672 & 4,672 & 4,672 & 4,581 & 27,891 \\
\hline Central African Rep. & 0 & 4,693 & 0 & 4,693 & 4,693 & 4,693 & 18,772 \\
\hline Chile & 0 & 4,745 & 4,745 & 4,745 & 4,745 & 4,739 & 23,719 \\
\hline China & 4,727 & 4,721 & 4,722 & 4,726 & 4,727 & 4,724 & 28,347 \\
\hline Colombia & 4,745 & 4,745 & 4,745 & 4,745 & 4,745 & 4,745 & 28,470 \\
\hline Costa Rica & 0 & 4,745 & 4,745 & 4,745 & 4,745 & 4,743 & 23,723 \\
\hline Ecuador & 4,745 & 4,745 & 4,745 & 4,745 & 4,745 & 4,745 & 28,470 \\
\hline El Salvador & 0 & 4,745 & 4,745 & 4,745 & 4,745 & 4,742 & 23,722 \\
\hline European Communities & 4,511 & 4,515 & 4,517 & 4,515 & 4,520 & 4,518 & 27,096 \\
\hline Gabon & 0 & 0 & 4,714 & 4,714 & 0 & 0 & 9,428 \\
\hline Guatemala & 0 & 4,720 & 4,720 & 4,720 & 4,720 & 4,719 & 23,599 \\
\hline
\end{tabular}


Table B.2. Number of observations of the sample in Table 2 (continued)

\begin{tabular}{|c|c|c|c|c|c|c|c|}
\hline & \multicolumn{3}{|c|}{ Beginning of period } & \multicolumn{3}{|c|}{ End of period } & \multirow[b]{2}{*}{ Total } \\
\hline & 1996 & 1997 & 1998 & 2009 & 2010 & 2011 & \\
\hline Honduras & 0 & 4,741 & 4,741 & 4,741 & 0 & 0 & 14,223 \\
\hline Hong Kong, China & 4,322 & 4,456 & 4,456 & 4,456 & 4,456 & 4,456 & 26,602 \\
\hline Iceland & 0 & 4,509 & 4,573 & 4,573 & 4,573 & 4,573 & 22,801 \\
\hline India & 4,481 & 4,489 & 1,872 & 4,489 & 0 & 0 & 15,331 \\
\hline Indonesia & 4,734 & 2,489 & 4,734 & 4,734 & 4,734 & 4,719 & 26,144 \\
\hline Japan & 4,632 & 4,636 & 4,636 & 4,636 & 4,636 & 4,636 & 27,812 \\
\hline Korea, Republic of & 4,727 & 4,718 & 4,718 & 4,727 & 4,727 & 4,711 & 28,328 \\
\hline Macao, China & 4,548 & 4,745 & 4,745 & 4,745 & 4,745 & 0 & 23,528 \\
\hline Madagascar & 4,742 & 4,743 & 4,743 & 4,095 & 4,743 & 4,743 & 27,809 \\
\hline Malaysia & 0 & 4,628 & 3,973 & 4,627 & 4,625 & 0 & 17,853 \\
\hline Mali & 0 & 0 & 4,737 & 0 & 4,737 & 0 & 9,474 \\
\hline Mauritius & 0 & 4,671 & 4,674 & 4,674 & 4,674 & 4,629 & 23,322 \\
\hline Mexico & 0 & 4,705 & 4,705 & 4,688 & 4,705 & 4,665 & 23,468 \\
\hline Nepal & 0 & 0 & 4,706 & 4,706 & 4,706 & 4,706 & 18,824 \\
\hline New Zealand & 4,729 & 4,729 & 4,729 & 4,729 & 4,724 & 0 & 23,640 \\
\hline Nicaragua & 0 & 4,745 & 4,745 & 4,745 & 4,729 & 0 & 18,964 \\
\hline Norway & 4,010 & 4,303 & 4,314 & 4,315 & 4,315 & 4,315 & 25,572 \\
\hline Panama & 0 & 0 & 4,534 & 4,534 & 4,534 & 4,534 & 18,136 \\
\hline Paraguay & 0 & 0 & 4,745 & 4,745 & 4,745 & 4,744 & 18,979 \\
\hline Peru & 0 & 0 & 5,040 & 5,040 & 4,745 & 4,745 & 19,570 \\
\hline Russian Federation & 0 & 4,205 & 0 & 4,204 & 4,179 & 4,161 & 16,749 \\
\hline Singapore & 0 & 4,721 & 4,722 & 4,722 & 4,722 & 0 & 18,887 \\
\hline Switzerland & 417 & 464 & 495 & 496 & 496 & 496 & 2,864 \\
\hline Tanzania & 0 & 4,736 & 4,712 & 4,737 & 4,743 & 4,740 & 23,668 \\
\hline Togo & 0 & 0 & 4,422 & 4,422 & 4,422 & 4,422 & 17,688 \\
\hline Turkey & 4,648 & 4,714 & 4,656 & 4,709 & 4,710 & 4,714 & 28,151 \\
\hline United States & 4,358 & 4,450 & 4,363 & 4,446 & 4,446 & 4,450 & 26,513 \\
\hline Uruguay & 0 & 4,745 & 4,745 & 4,745 & 0 & 0 & 14,235 \\
\hline Zambia & 0 & 4,745 & 0 & 4,745 & 4,745 & 4,743 & 18,978 \\
\hline Total & 83,097 & 180,575 & 194,032 & 210,462 & 196,844 & 163,041 & $1,028,051$ \\
\hline
\end{tabular}




\section{Appendix C: Trade policy uncertainty for specific countries and sectors}

Table C.1. MFN applied tariff increases 1996-2011, top 10 countries

\begin{tabular}{|c|c|c|c|c|c|}
\hline & $\begin{array}{l}\text { Number of } \\
\text { lines with } \\
\text { tariff } \\
\text { increases }\end{array}$ & & $\begin{array}{l}\text { Size of tariff } \\
\text { increase } \\
\text { (percentage } \\
\text { points) }\end{array}$ & & $\begin{array}{c}\text { Percentage of } \\
\text { imports with tariff } \\
\text { increases }\end{array}$ \\
\hline Guinea & $1,632.5$ & S. Kitts and Nevis & 64.6 & Guinea & 74.0 \\
\hline Mauritania & $1,460.0$ & Oman & 34.2 & Mongolia & 41.8 \\
\hline Mongolia & 1,328.9 & Seychelles & 25.4 & Lebanon & 33.6 \\
\hline Fiji & 938.6 & Barbados & 24.5 & Rwanda & 28.1 \\
\hline Lebanon & 843.3 & Rwanda & 20.5 & Malta & 27.4 \\
\hline Costa Rica & 838.5 & Mauritius & 19.8 & Qatar & 23.4 \\
\hline Argentina & 756.3 & India & 18.6 & Paraguay & 23.0 \\
\hline Malta & 713.4 & Norway & 18.4 & Iran & 22.6 \\
\hline Paraguay & 604.9 & Tunisia & 15.8 & Mauritania & 22.2 \\
\hline Sri Lanka & 600.7 & Poland & 15.5 & Fiji & 20.4 \\
\hline
\end{tabular}

Notes: Averages are calculated by first obtaining the number of increases, average size of the increase and percentage of imports with tariff increase by country-year. Then, averages across years within countries are computed. The percentage of imports represents the percentage of $t-1$ imports for which we register a tariff increase at time $t$. The sample includes those country-product pairs for which we have information on lagged imports and tariff changes in at least one of the years 19972011. 
Table C.2. MFN applied tariff increases 1996-2011, top 10 HS2 sectors

\begin{tabular}{|c|c|c|c|c|c|}
\hline HS & & $\begin{array}{c}\text { Number } \\
\text { of lines }\end{array}$ & HS & & $\begin{array}{l}\text { Number of } \\
\text { countries }\end{array}$ \\
\hline 84 & Nuclear reactors, boilers, mchy \& mech appliance; parts. & $1,462.6$ & 85 & Electrical mchy equip parts thereof; sound recorder etc & 40.9 \\
\hline 85 & Electrical mchy equip parts thereof; sound recorder etc & 886.3 & 84 & Nuclear reactors, boilers, mchy \& mech appliance; parts & 40.4 \\
\hline 29 & Organic chemicals. & 730.4 & 87 & Vehicles o/t railw/tramw roll-stock, pts \& accessories & 32.3 \\
\hline 72 & Iron and steel. & 484.0 & 39 & Plastics and articles thereof. & 31.0 \\
\hline 90 & Optical, photo, cine, meas, checking, precision, etc & 435.5 & 90 & Optical, photo, cine, meas, checking, precision, etc & 30.4 \\
\hline 39 & Plastics and articles thereof. & 377.1 & 48 & Paper \& paperboard; art of paper pulp, paper/paperboard & 30.3 \\
\hline 52 & Cotton. & 371.2 & 29 & Organic chemicals. & 28.1 \\
\hline 28 & Inorgn chem; compds of prec mtl, radioact elements etc & 367.0 & 38 & Miscellaneous chemical products. & 26.5 \\
\hline 62 & Art of apparel \& clothing access, not knitted/crocheted & 356.8 & 40 & Rubber and articles thereof. & 26.1 \\
\hline 73 & Articles of iron or steel. & 351.6 & 73 & Articles of iron or steel. & 24.0 \\
\hline HS & & Size & HS & & $\begin{array}{l}\text { Percentage } \\
\text { of imports }\end{array}$ \\
\hline 4 & Dairy prod; birds' eggs; natural honey; edible prod nes & 14.4 & 6 & Live tree \& other plant; bulb, root; cut flowers etc & 10.1 \\
\hline 2 & Meat and edible meat offal & 14.3 & 10 & Cereals & 9.7 \\
\hline 24 & Tobacco and manufactured tobacco substitutes & 13.8 & 21 & Miscellaneous edible preparations. & 8.2 \\
\hline 10 & Cereals & 13.0 & 29 & Organic chemicals. & 7.8 \\
\hline 22 & Beverages, spirits and vinegar. & 12.6 & 15 & Animal/veg fats \& oils \& their cleavage products; etc & 7.7 \\
\hline 17 & Sugars and sugar confectionery. & 12.3 & 46 & Manufactures of straw, esparto/other plaiting mat; etc & 7.5 \\
\hline 16 & Prep of meat, fish or crustaceans, molluscs etc & 10.9 & 7 & Edible vegetables and certain roots and tubers. & 7.0 \\
\hline 7 & Edible vegetables and certain roots and tubers. & 10.9 & 38 & Miscellaneous chemical products. & 6.9 \\
\hline 11 & Prod.mill.indust; malt; starches; inulin; wheat gluten & 10.7 & 3 & Fish \& crustacean, mollusc \& other aquatic invertebrate & 6.3 \\
\hline 13 & Lac; gums, resins \& other vegetable saps \& extracts. & 10.2 & 17 & Sugars and sugar confectionery. & 6.1 \\
\hline
\end{tabular}

Notes: Averages are calculated by first obtaining the number of increases, average size of the increase, number of countries and percentage of imports with tariff increase by industry-year (an industry is defined at the 2-digit HS 1996 classification). Then, averages across years within industries are computed. The percentage of imports represents the percentage of $t-1$ imports for which we register a tariff increase at time $t$. The sample includes those country-product pairs for which we have information on lagged imports and tariff changes in at least one of the years 1997-2011. 


\section{Appendix D: Summary statistics of the main variables}

Table D.1 Summary statistics of the main variables used in the econometric analysis

\begin{tabular}{|c|c|c|c|c|c|}
\hline & Mean & Min & Max & $\begin{array}{c}\text { Standard } \\
\text { Deviation } \\
\end{array}$ & $\begin{array}{c}\text { Number of } \\
\text { observations }\end{array}$ \\
\hline \multicolumn{6}{|l|}{ Dependent variables } \\
\hline $\begin{array}{l}\text { MFN applied tariff increased between } t \text { - } \\
1 \text { and } t\end{array}$ & 0.03 & 0.00 & 1.00 & 0.18 & $3,208,097$ \\
\hline Ln(1 + Size of MFN applied tariff & & & & & \\
\hline increase) $)_{\mathrm{ckt}-1}$ & 0.05 & 0.00 & 6.50 & 0.29 & $3,208,097$ \\
\hline \multicolumn{6}{|l|}{ Explanatory variables } \\
\hline$\Delta(\text { Share of imports })_{\text {ckt-1 }}$ & 0.00 & -0.99 & 1.00 & 0.02 & $3,208,097$ \\
\hline Std. Dev. of $\Delta$ (Share of imports $)_{\mathrm{ck}}$ & 0.01 & 0.00 & 0.59 & 0.02 & $3,208,097$ \\
\hline Share of imports $\mathrm{ck}_{\mathrm{k}}$ & 0.01 & 0.00 & 0.96 & 0.05 & $3,208,097$ \\
\hline $\operatorname{Ln}(1+\text { Bound rate })_{\mathrm{ckt}}$ & 0.79 & 0.00 & 9.15 & 0.40 & $3,208,097$ \\
\hline $\operatorname{Ln}(1+\text { MFN applied tariff })_{\text {ckt-1 }}$ & 0.08 & 0.00 & 2.40 & 0.09 & $3,208,097$ \\
\hline $\operatorname{Ln}(1+\text { Prohibitive tariff })_{\mathrm{ckt}}$ & 0.79 & 0.00 & 9.15 & 0.40 & $3,208,097$ \\
\hline $\operatorname{Ln}(G D P)_{\mathrm{ct}-1}$ & 24.68 & 19.97 & 30.54 & 2.28 & $3,208,097$ \\
\hline GDP growth ct-1 $_{1}$ & 0.10 & -0.62 & 0.55 & 0.13 & $3,208,097$ \\
\hline Average PTA depth $\mathrm{ct}_{\mathrm{c}}$ & 9.48 & 0.00 & 21.00 & 5.09 & $3,208,097$ \\
\hline$(\text { Custom Union)*(Average PTA depth) })_{\mathrm{ct}}$ & 4.66 & 0.00 & 20.00 & 5.57 & $3,208,097$ \\
\hline Custom Union & 0.50 & 0.00 & 1.00 & 0.50 & $3,208,097$ \\
\hline Trade Policy Review ${ }_{\mathrm{ct}-1}$ & 0.16 & 0.00 & 1.00 & 0.37 & $3,208,097$ \\
\hline Water $_{\text {ckt }}$ & 0.17 & -9.92 & 4.54 & 0.23 & $3,208,097$ \\
\hline Effective water $_{\text {ckt }}$ & 0.16 & -9.92 & 3.15 & 0.20 & $3,208,097$ \\
\hline
\end{tabular}

Notes: The table considers the sample from our most complete estimated logit model (Table 6, column 3). 


\section{Appendix E: Linear Probability Model (LPM) estimations}

Table E.1: Augmenting B\&S model to account for WTO flexibility (LPM)

\begin{tabular}{|c|c|c|c|c|c|c|}
\hline & \multicolumn{6}{|c|}{ Dependent variable: $1=$ MFN applied tariff increase } \\
\hline & \multicolumn{3}{|c|}{ Full sample } & \multicolumn{3}{|c|}{$\mathrm{G}-20$} \\
\hline & $(1)$ & $(2)$ & $(3)$ & (4) & $(5)$ & (6) \\
\hline $\operatorname{Ln}(1+\text { Bound rate })_{\text {ckt }}$ & $\begin{array}{c}0.207 * * * \\
{[0.013]}\end{array}$ & & & $\begin{array}{c}0.389 * * * \\
{[0.032]}\end{array}$ & & \\
\hline $\operatorname{Ln}(1+\text { Prohibitive tariff })_{\mathrm{ckt}}$ & $\begin{array}{c}0.009 * * * \\
{[0.000]}\end{array}$ & & & $\begin{array}{c}0.008^{* * *} \\
{[0.000]}\end{array}$ & & \\
\hline Ln(1 + MFN applied tariff $)_{\text {ckt- } 1}$ & $\begin{array}{c}-0.599 * * * \\
{[0.013]}\end{array}$ & & & $\begin{array}{c}-0.682 * * * \\
{[0.032]}\end{array}$ & & \\
\hline Water $_{\text {ckt }}$ & & $\begin{array}{c}0.240^{* * *} \\
{[0.010]}\end{array}$ & & & $\begin{array}{c}0.283^{* * *} \\
{[0.033]}\end{array}$ & \\
\hline Effective water $_{\text {ckt }}$ & & & $\begin{array}{c}0.131^{* * *} \\
{[0.003]}\end{array}$ & & & $\begin{array}{c}0.215^{* * *} \\
{[0.017]}\end{array}$ \\
\hline$\Delta(\text { Share of imports })_{\text {ckt-1 }}$ & $\begin{array}{l}0.008^{*} \\
{[0.004]}\end{array}$ & $\begin{array}{c}0.007 \\
{[0.004]}\end{array}$ & $\begin{array}{l}0.008^{*} \\
{[0.004]}\end{array}$ & $\begin{array}{c}0.002 \\
{[0.006]}\end{array}$ & $\begin{array}{c}0.002 \\
{[0.005]}\end{array}$ & $\begin{array}{c}0.004 \\
{[0.006]}\end{array}$ \\
\hline Std. Dev. of $\Delta$ (Share of imports $)_{\mathrm{ck}}$ & $\begin{array}{c}-0.046 * * * \\
{[0.005]}\end{array}$ & $\begin{array}{c}-0.040 * * * \\
{[0.005]}\end{array}$ & $\begin{array}{c}-0.043^{* * * *} \\
{[0.005]}\end{array}$ & $\begin{array}{c}-0.072 * * * \\
{[0.010]}\end{array}$ & $\begin{array}{c}-0.064 * * * \\
{[0.009]}\end{array}$ & $\begin{array}{c}-0.072^{* * *} \\
{[0.009]}\end{array}$ \\
\hline Share of imports ${ }_{\mathrm{ck}}$ & $\begin{array}{c}0.023^{* * *} \\
{[0.004]}\end{array}$ & $\begin{array}{c}0.028 * * * \\
{[0.004]}\end{array}$ & $\begin{array}{c}0.028^{* * *} \\
{[0.004]}\end{array}$ & $\begin{array}{c}0.029 * * * \\
{[0.005]}\end{array}$ & $\begin{array}{c}0.032 * * * \\
{[0.004]}\end{array}$ & $\begin{array}{c}0.032 * * * \\
{[0.004]}\end{array}$ \\
\hline Observations & $4,101,618$ & $4,205,819$ & $4,101,618$ & 836,530 & 858,049 & 836,530 \\
\hline Year FE & NO & NO & NO & NO & NO & NO \\
\hline Country FE & NO & NO & NO & NO & NO & NO \\
\hline Sector4dig FE & NO & NO & NO & NO & NO & NO \\
\hline CountrySector4dig FE & YES & YES & YES & YES & YES & YES \\
\hline CountryYear FE & YES & YES & YES & YES & YES & YES \\
\hline R-squared & 0.486 & 0.484 & 0.480 & 0.429 & 0.429 & 0.423 \\
\hline
\end{tabular}

Note: The samples only include bound lines. ***, **, *, indicate significance at 1, 5, and 10 percent. Robust standard errors in parentheses, clustered by country-industry (4 digit). 


\section{Appendix F: Marginal effects}

Table F.1: An empirical model of trade policy uncertainty (logit marginal effects)

\begin{tabular}{|c|c|c|c|c|c|c|c|c|}
\hline & \multicolumn{8}{|c|}{ Dependent variable: $1=$ MFN applied tariff increase } \\
\hline & \multicolumn{5}{|c|}{ Full sample } & \multicolumn{3}{|c|}{ G-20 } \\
\hline & (1) & (2) & (3) & (4) & (5) & (6) & (7) & (8) \\
\hline \multicolumn{9}{|l|}{ WTO flexibility } \\
\hline $\operatorname{Ln}(1+\text { Bound rate })_{\mathrm{ckt}}$ & $\begin{array}{c}0.023^{* * *} \\
{[0.001]}\end{array}$ & $\begin{array}{c}0.026^{* * *} \\
{[0.001]}\end{array}$ & $\begin{array}{c}0.026^{* * *} \\
{[0.001]}\end{array}$ & & & $\begin{array}{c}0.022 * * * \\
{[0.002]}\end{array}$ & & \\
\hline $\operatorname{Ln}(1+\text { Prohibitive tariff })_{\mathrm{ckt}}$ & $\begin{array}{c}0.003^{* * *} \\
{[0.000]}\end{array}$ & $\begin{array}{c}0.003 * * * \\
{[0.000]}\end{array}$ & $\begin{array}{c}0.003^{* * *} \\
{[0.000]}\end{array}$ & & & $\begin{array}{c}-0.056^{* * * *} \\
{[0.005]}\end{array}$ & & \\
\hline Ln(1 + MFN applied tariff $)_{\text {ckt-1 }}$ & $\begin{array}{c}-0.076 * * * \\
{[0.002]}\end{array}$ & $\begin{array}{c}-0.069 * * * \\
{[0.002]}\end{array}$ & $\begin{array}{c}-0.068^{* * *} \\
{[0.002]}\end{array}$ & & & $\begin{array}{c}0.002 * * * \\
{[0.000]}\end{array}$ & & \\
\hline Water $_{\text {ckt }}$ & & & & $\begin{array}{c}0.016^{* * *} \\
{[0.001]}\end{array}$ & & & $\begin{array}{c}0.013^{* * * *} \\
{[0.001]}\end{array}$ & \\
\hline Effective water $_{\text {ckt }}$ & & & & & $\begin{array}{c}0.020^{* * *} \\
{[0.001]}\end{array}$ & & & $\begin{array}{c}0.019 * * * \\
{[0.001]}\end{array}$ \\
\hline \multicolumn{9}{|l|}{ Bagwell and Staiger's model } \\
\hline$\Delta(\text { Share of imports })_{\text {ckt }-1}$ & $\begin{array}{c}0.017 * * * \\
{[0.002]}\end{array}$ & $\begin{array}{c}0.015^{* * *} \\
{[0.002]}\end{array}$ & $\begin{array}{c}0.015^{* * *} \\
{[0.002]}\end{array}$ & $\begin{array}{c}0.015^{* * *} \\
{[0.002]}\end{array}$ & $\begin{array}{c}0.016^{* * *} \\
{[0.002]}\end{array}$ & $\begin{array}{c}0.005^{*} \\
{[0.003]}\end{array}$ & $\begin{array}{c}0.006 * * \\
{[0.003]}\end{array}$ & $\begin{array}{l}0.006 * * \\
{[0.003]}\end{array}$ \\
\hline Std. Dev. of $\Delta$ (Share of imports) $)_{\mathrm{ck}}$ & $\begin{array}{c}-0.013^{* * * *} \\
{[0.003]}\end{array}$ & $\begin{array}{c}-0.013^{* * *} \\
{[0.003]}\end{array}$ & $\begin{array}{c}-0.012 * * * \\
{[0.003]}\end{array}$ & $\begin{array}{c}-0.011^{* * *} \\
{[0.003]}\end{array}$ & $\begin{array}{c}-0.013^{* * *} \\
{[0.003]}\end{array}$ & $\begin{array}{c}-0.008^{* *} \\
{[0.003]}\end{array}$ & $\begin{array}{c}-0.010^{* * *} \\
{[0.003]}\end{array}$ & $\begin{array}{c}-0.011^{* * *} \\
{[0.003]}\end{array}$ \\
\hline Share of imports ${ }_{\mathrm{ck}}$ & $\begin{array}{c}0.014 * * * \\
{[0.002]}\end{array}$ & $\begin{array}{c}0.013^{* * *} \\
{[0.002]}\end{array}$ & $\begin{array}{c}0.013^{* * *} \\
{[0.002]}\end{array}$ & $\begin{array}{c}0.016^{* * *} \\
{[0.002]}\end{array}$ & $\begin{array}{c}0.016^{* * *} \\
{[0.002]}\end{array}$ & $\begin{array}{c}0.014 * * * \\
{[0.002]}\end{array}$ & $\begin{array}{c}0.016^{* * *} \\
{[0.002]}\end{array}$ & $\begin{array}{c}0.016^{* * *} \\
{[0.002]}\end{array}$ \\
\hline
\end{tabular}


Table F.1: An empirical model of trade policy uncertainty (logit marginal effects) - continued

\begin{tabular}{|c|c|c|c|c|c|c|c|c|}
\hline & \multicolumn{8}{|c|}{ Dependent variable: $1=$ MFN applied tariff increase } \\
\hline & \multicolumn{5}{|c|}{ Full sample } & \multicolumn{3}{|c|}{ G-20 } \\
\hline & $(1)$ & $(2)$ & $(3)$ & $(4)$ & (5) & $(6)$ & $(7)$ & $(8)$ \\
\hline \multicolumn{9}{|l|}{ Economic and institutional variables } \\
\hline $\ln (G D P)_{\mathrm{ct}-1}$ & $\begin{array}{c}-0.010 * * * \\
{[0.000]}\end{array}$ & $\begin{array}{c}-0.009 * * * \\
{[0.000]}\end{array}$ & $\begin{array}{c}-0.009 * * * \\
{[0.000]}\end{array}$ & $\begin{array}{c}-0.010 * * * \\
{[0.000]}\end{array}$ & $\begin{array}{c}-0.009 * * * \\
{[0.000]}\end{array}$ & $\begin{array}{c}-0.011^{* * *} \\
{[0.001]}\end{array}$ & $\begin{array}{c}-0.011^{* * *} \\
{[0.001]}\end{array}$ & $\begin{array}{c}-0.011^{* * *} \\
{[0.001]}\end{array}$ \\
\hline GDP growth $_{\mathrm{ct}-1}$ & $\begin{array}{c}-0.010 * * * \\
{[0.001]}\end{array}$ & $\begin{array}{c}-0.010 * * * \\
{[0.001]}\end{array}$ & $\begin{array}{c}-0.010^{* * *} \\
{[0.001]}\end{array}$ & $\begin{array}{c}-0.010 * * * \\
{[0.001]}\end{array}$ & $\begin{array}{c}-0.010^{* * *} \\
{[0.001]}\end{array}$ & $\begin{array}{c}-0.005^{* * *} \\
{[0.001]}\end{array}$ & $\begin{array}{c}-0.006^{* * *} \\
{[0.001]}\end{array}$ & $\begin{array}{c}-0.006^{* * *} \\
{[0.001]}\end{array}$ \\
\hline Average PTA depth ${ }_{\mathrm{ct}}$ & & $\begin{array}{c}0.001^{* * *} \\
{[0.000]}\end{array}$ & $\begin{array}{c}0.001^{* * *} \\
{[0.000]}\end{array}$ & $\begin{array}{c}0.002^{* * *} \\
{[0.000]}\end{array}$ & $\begin{array}{c}0.002^{* * *} \\
{[0.000]}\end{array}$ & $\begin{array}{c}0.002^{* * *} \\
{[0.000]}\end{array}$ & $\begin{array}{c}0.002^{* * *} \\
{[0.000]}\end{array}$ & $\begin{array}{c}0.002^{* * *} \\
{[0.000]}\end{array}$ \\
\hline 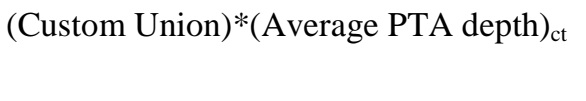 & & $\begin{array}{c}-0.000 \\
{[0.000]}\end{array}$ & $\begin{array}{c}-0.000 \\
{[0.000]}\end{array}$ & $\begin{array}{c}-0.000 \\
{[0.000]}\end{array}$ & $\begin{array}{c}-0.000 \\
{[0.000]}\end{array}$ & $\begin{array}{c}0.002^{* * *} \\
{[0.000]}\end{array}$ & $\begin{array}{c}0.002^{* * *} \\
{[0.000]}\end{array}$ & $\begin{array}{c}0.002^{* * *} \\
{[0.000]}\end{array}$ \\
\hline Custom Union & & $\begin{array}{c}-0.017 * * * \\
{[0.002]}\end{array}$ & $\begin{array}{c}-0.017 * * * \\
{[0.002]}\end{array}$ & $\begin{array}{c}-0.019 * * * \\
{[0.002]}\end{array}$ & $\begin{array}{c}-0.018^{* * *} \\
{[0.002]}\end{array}$ & $\begin{array}{c}-0.012 * * * \\
{[0.002]}\end{array}$ & $\begin{array}{c}-0.013^{* * *} \\
{[0.002]}\end{array}$ & $\begin{array}{c}-0.013^{* * *} \\
{[0.002]}\end{array}$ \\
\hline Trade Policy Review ${ }_{\mathrm{ct}-1}$ & & & $\begin{array}{c}-0.003 * * * \\
{[0.000]}\end{array}$ & $\begin{array}{c}-0.003^{* * *} \\
{[0.000]}\end{array}$ & $\begin{array}{c}-0.003^{* * *} \\
{[0.000]}\end{array}$ & $\begin{array}{c}-0.006 * * * \\
{[0.000]}\end{array}$ & $\begin{array}{c}-0.007^{* * *} \\
{[0.000]}\end{array}$ & $\begin{array}{c}-0.007 * * * \\
{[0.000]}\end{array}$ \\
\hline Observations & $3,908,940$ & $3,208,097$ & $3,208,097$ & $3,289,876$ & $3,208,097$ & 793,236 & 813,493 & 793,236 \\
\hline Year FE & YES & YES & YES & YES & YES & YES & YES & YES \\
\hline Country FE & YES & YES & YES & YES & YES & YES & YES & YES \\
\hline Sector4dig FE & YES & YES & YES & YES & YES & YES & YES & YES \\
\hline
\end{tabular}

Note: The samples only include bound lines. ${ }^{* *}, * *, *$, indicate significance at 1,5 , and 10 percent. Robust standard errors in parentheses, clustered by country-industry ( 4 digit) 